\title{
A meta-analysis of the quantitative studies in continuance intention to use an information system
}

Frank Bivar Franque (Engineering College, Universidade Católica de Moçambique, Chimoio, Mozambique) (NOVA Information Management School (NOVA IMS), Universidade Nova de Lisboa, Lisbon, Portugal)

Tiago Oliveira (NOVA Information Management School (NOVA IMS), Universidade Nova de Lisboa, Lisbon, Portugal)

Carlos Tam (NOVA Information Management School (NOVA IMS), Universidade Nova de Lisboa, Lisbon, Portugal)

Fernando de Oliveira Santini (Graduate Program in Administration, Universidade do Vale do Rio dos Sinos, Porto Alegre, Brazil)

This is the accepted author manuscript of the following article published by EMERALD:

Franque, F. B., Oliveira, T., Tam, C., \& Santini, F. D. O. (2021). A meta-analysis of the quantitative studies in continuance intention to use an information system. Internet Research, 31(1), 1-36. [advanced online publication on 7 August 2020].

https://doi.org/10.1108/INTR-03-2019-0103

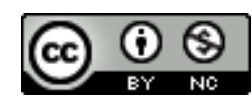

This work is licensed under a Creative Commons Attribution-NonCommercial 4.0 International License. 


\title{
A meta-analysis of the quantitative studies in continuance intention to use an information system
}

\begin{abstract}
Purpose

This study aims to describe, synthesise, and clarify the findings of published studies on individual continuance intention to use an information system (IS), considering the fact that the number of studies in the continuance intention context are growing exponentially and cover several different subjects.
\end{abstract}

\section{Design/methodology}

The research uses meta- and weight analysis by taking 115 empirical studies from continuance intention to use an IS. The data are presented in different views using significant and nonsignificant relationships from all the studies. Furthermore, it uses hierarchical linear meta-analysis to analyse potential moderators that can influence continuance intention.

\section{Findings}

The results reveal that affective commitment, attitude, satisfaction, hedonic value, and flow are the best predictors of continuance intention to use an IS. Sample size, individualism, uncertainty avoidance, and long-term orientation moderate the relationship of perceived usefulness on continuance intention. Power distance, masculinity, and indulgence moderate relationship satisfaction on continuance intention.

\section{Practical implications}

The results reveal that continuance intention to use an IS has been studied in different countries, with different cultures; therefore, IS providers should have diversified managing strategies, to ensure the satisfaction of users and long-term usage of their IS.

\section{Originality/value}


The study provides a systematic overview of the most relevant variables used in the literature, including a temporal analysis of the theoretical models, highlighting the evolution of the constructs and presents a moderation analysis.

Keywords: IS Continuance intention; IS post-usage; Literature review; Meta-analysis; Weight analysis. 


\section{A Meta-analysis of the quantitative studies in continuance intention to use an information system}

\section{Introduction}

The evolution of information systems (IS) has offered the opportunity to different types of institutions to advance the capability, efficiency, and responsibility of their services and products, thereby streamlining the day to day activities of their customers (Laukkanen 2007). Its use is growing exponentially, considering the usefulness of IS in society. However, the adoption of IS is not enough to keep them in the market, continuous use is necessary (Bhattacherjee, 2001), to bring a return on the investments that companies make, and to help the users in their activities. Continuous use of IS refers to the decision of the user to continue to use the IS. This behaviour is noted after the user has the first experience with IS. Understanding what factors influence an individual to continue to use IS has become necessary for researchers and companies (Bhattacherjee, 2001; Shaikh and Karjaluoto, 2015). In recent years, the number of studies in continuance intention to use an IS has grown rampantly and now covers several subjects such as continuance intention in mobile banking services, mobile payment, e-learning, social networking, health applications, e-government, mobile commerce, among others. Considering that the number of studies is growing, different technologies, theories and contexts are being studied, there is plenty of scattered information and different results. With that much information in the background, the process of searching for studies became more difficult, and the need for comprehensive and synthesised information about IS continuance intention became essential.

Therefore, it is crucial and necessary to highlight, summarise and clarify the results of existing studies in order to provide a comprehensive picture of continuing to use IS (Fettke, 2006). This process enables theory development and reveals new relationships and gaps (Hamari and Keronen, 2017). There are some literature reviews on IS continuous intention (e.g., Bhattacherjee and Barfar, 2011; Shaikh and Karjaluoto, 2015; Nabavi et al., 2016), that explore different aspects of prior studies such as theories, technologies, and used contexts. However, most of them are narrative and descriptive; none of them has used meta-analysis. This study will use meta- and weight analysis to derive for more empirical results. The meta-analysis is a process of summarising, evaluating, and analysing quantitative research findings (Zhang et al., 2012), even if the outcome is non-significant or inconsistent, it can contributes to a pooled conclusion, 
reinforcing the general validity of the interpretations (Hamari and Keronen, 2017; Wu et al., 2011). According to earlier research meta-analysis and weight analysis are considered appropriate methods to review empirical data (Baptista and Oliveira, 2016; Rana et al., 2015; Schmidt and Hunter, 2016; Zhao et al., 2018). We describe the most critical variables in the field, using findings reported in existing research combined with weight analysis of the constructs to identify the best predictors (Zhao et al., 2018) to highlight the best predictors of continuance intention to use an IS, improvements of theories, and the strength of the variables.

According to our knowledge, no research addresses: (i) meta-analysis combined with weight analysis in the context of continuance intention to use an IS, or (ii) temporal analysis to understand the evolution of the theoretical models over time. This study can extrapolate broader theoretical implications relating to the positioning and understanding of IS. Contributing to the research, we illustrate the most used relationships, best predictors, most used technologies during a period, the evolution of the number of papers per year, and the evolution of the theoretical model. The overall variables to be used to predict continuance intention to use an IS were illustrated. Beyond synthesising the main findings of the studies, we also created models to understand the temporal evolution of the constructs better. Additionally, we analysed possible moderators in the relationship between perceived usefulness and satisfaction on continuance intention to use IS.

The article is organised as follows: in Section 2, is presented the literature review, Section 3 describes the research methodology; in the next section, we present the results of the research followed by a discussion of the findings; the conclusion and future recommendations follow this section.

\section{Information system continuance intention (ISCI) background}

Continuance intention of IS refers to factors that contribute to IS usage for a long time. It involves understanding the long-term factors that contribute to the success of the IS (Bhattacherjee, 2001; Lin et al., 2017; Wang, 2015). The first ISCI model was developed by Bhattacherjee, (2001), who proposed that (1) confirmation of the expectations positively influences perceived usefulness and user satisfaction. (2) Perceived usefulness positively influences user satisfaction and continuance intention to use an IS, and (3) user satisfaction positively influences continuance intention to use an IS. Additionally, after Bhattacherjee, (2001) proposed the expectation-confirmation model 
(ECM), it has been extensively tested in several studies and confirmed that it is a robust model to explain ISCI (Carillo et al., 2017; Hadji and Degoulet, 2016; Hong et al., 2017a; Hsiao et al., 2016; Zheng, 2019). Thereby, many of the early studies used ECM as a base model, and integrated other theories to study different technologies. Susanto et al., (2016) used it to explain smartphone banking services. Lee (2010) applied it to explain e-learning. Alraimi et al., (2015) used it to explain MOOCs. Gao et al., (2015) used it to explain mobile purchases.

Prior studies have conducted literature reviews in the context of IS. However, most of these studies have explored and summarised the literature on a specific IS such as Zolotov et al., (2018) in eparticipation, Shaikh and Karjaluoto, (2015) in m-banking, Bayramusta and Nasir, (2016) in cloud computing, Albuquerque et al., (2016) in m-payment. Therefore, in the context of ISCI, we found some reviews that address several issues around ISCI such as theories used, scientific journals published, technologies used, regions studied, number of publications per year, among others (Bhattacherjee and Barfar, 2011; Nabavi et al., 2016; Shaikh and Karjaluoto, 2015). However, none of the studies used meta-analysis in the context of ISCI, thus, becoming essential to review empirical data to bring more insights to the literature (Frohberg et al., 2009). A literature review is a process of summarising and highlighting research results. There are different types of review, such as narrative reviews, literature reviews, meta-analysis, to name a few. A narrative review is broader than a literature review, and meta-analysis is more empirical than a literature review (Frohberg et al., 2009; Shaikh and Karjaluoto, 2015).

Despite finding some qualitative reviews that addressed several issues of ISCI (Bhattacherjee and Barfar, 2011; Nabavi et al., 2016; Shaikh and Karjaluoto, 2015), and the relevant contribution of qualitative studies, the results did not exhibit conclusive and generalised findings as meta-analytic studies promote (Schmidt. and Hunter, 2004). In the literature review conducted by Bhattacherjee and Barfar, (2011), the purpose was to align the misunderstanding of the concepts, and theory concerning ISCI and extend the theoretical model. The analysis range was ten years, and they found 15 empirical articles. They identified studies that had used acceptance theories such as technology acceptance model (TAM) or unified theory of acceptance and use of technology (UTAUT), to predict continuance intention. Thus, the authors suggest that this practice may be inconsistent and inappropriate to predict ISCI. They also verified that many studies employed a 
Shaikh and Karjaluoto (2015) conducted a literature review on IS technology/usage. The range of analysis was 15 years, counting 152 studies. In this study, the scope was to synthesise and segregate the major domains of ISCI according to nature and usage. The primary findings of the study were that $75 \%$ of the studies predicted continuance intention to use IT/S as a proxy for actual use. They found that $58 \%$ of the studies on IT/S were published from 2010 to 2014 . $61 \%$ of the articles were found in ScienceDirect and Wiley scholarly databases. The authors classified the IT/S into four domains: Continuous Usage of Mobile Information Systems, Continuous Usage of Electronic Business Information Systems, Continuous Usage of Social Information Systems, and Continuous Usage of Electronic Learning Information Systems. Computers in Human Behaviour, Information Systems Journal, and Information and Management were identified as the publications that disseminated more articles on ISCI. Most of the studies were conducted in East Asia, followed by North America. No studies were conducted in Africa. Finally, ECM was the most used theoretical model, and most of the studies used quantitative research.

Nabavi et al., (2016) conducted a systematic review of 191 papers in the context of ISCI, in a range of 13 years. The goal of this study was to summarise the findings according to year, journal, country, author, research method, theories, to name a few. The authors verified that the journals Behaviour and Information Technology, Computers in Human Behaviour, Information and Management, Decision Support Systems, and MIS Quarterly dominate the literature use. Most of the studies were conducted in East Asia and North America, with no studies in Africa. Most of the respondents were students. Quantitative research was the most used method, and finally, the authors suggest that future studies could develop meta-analyses in the context of ISCI.

Considering that the above literature reviews in the context of ISCI were qualitative, reporting which technologies were used, methods, countries, type of respondents, theories and journals, no attempt has been made to conduct a quantitative review of ISCI. Considering that most of the studies reported in these literature reviews used a quantitative research design, it is proposed for this study to perform a meta and moderator analysis. By conducting this study, we expect to contribute to the IS discipline. From the results obtained in this investigation, it is possible to 
consolidate and generalise the relationships tested with continuance intention (Schmidt. and Hunter, 2004).

\section{Research methodology}

The study analyses and summarises the current findings on the IS continuance intention models. The process of literature selection was based on the following criteria. First, we chose the appropriate keywords for our research, such as continuance intention, post-adoption, continuance usage, continuance behaviour, continuance usage intention, continuance intention to use, IT continuance, IS continuance, and IS continuance theory in all possible combinations. Next, we applied the keywords in different research databases (Scopus, ACM digital library, EBSCO, Emerald, Taylor \& Francis, Springer, Web of Science, Science Direct, JSTOR, and Google Scholar), taking into consideration the logical operators such as AND, and OR (Hamari and Keronen, 2017).

After searching in the databases, we found more than 1000 articles related to the keywords used in the query. Some articles were duplicated; in this case, they were excluded. We opened each article, read the abstracts, verified if the articles are related to the IS, and if they presented a theoretical model, and quantitative data to validate them. After the verification, we found 181 articles. We then applied other criteria to assess the research relevance. To ensure the inclusion of relevant and current developments, we adopted the following criteria:

- $\quad$ The period studied ranges from 2001 to 2017;

- The studies were published under a peer review process;

- The studies analysed at an individual level;

- The type of study had to be quantitative;

- The studies had to show correlation coefficients between the variables used to support the theoretical model;

- The construct continuance intention or continuance behaviour had to be the outcome of the theoretical models;

- The datasets (databases) of the studies had to be independent; 
- Studies that used secondary databases or samples or databases that other studies had already used were excluded in order to avoid biases (Baptista and Oliveira, 2016; Wood, 2007).

Research that had multiple independent databases or samples (longitudinal studies) were included. E.g., Zhou et al., (2015) contributed with four datasets; Lee et al., (2007) contributed with three datasets; Lowry et al., (2015) contributed with three datasets. After this, we found 115 articles and 129 datasets for our research. This approach is considered suitable sampling compared to other studies published in top-level journals, e.g. Zhao et al., (2017) with 35 studies, Hamari and Keronen, (2017) with 48 studies, Zhang et al., (2012) with 53 studies, Šumak et al., (2011) with 42 studies, Gerow et al., (2014) with 30 studies, Wu et al., (2011) with 128 studies, Baptista and Oliveira, (2016), which included 57 studies, and Rana et al., (2015) with 63 studies. Figure 1 summarises the process to select the relevant articles for our research.

$<<$ Insert Figure 1 here $>>$

According to Rana et al., (2015) and Baptista and Oliveira, (2016), the relationships that were examined three or more times in the studies were selected, summarising 60 relationships. Weight analysis for each relationship was performed based on the number of significant relationships and the total number of relationships (Rana et al., 2015). We have used a random effect to calculate the estimated effect size variability between studies. We consider random effect appropriate because it considers the variation between studies and variation between study methods. Fixed effect methods only consider the variation between studies because of the sampling participation (Schmidt. and Hunter, 2004).

After the extraction of the correlation coefficients of the variable relationships, a single cumulative value was calculated for each of the relationships. These values, combined with study total sample sizes, supported the findings of the meta-analysis. We used the free software meta-essentials 1.1 (Rhee et al., 2015) to obtain the meta-analysis results. Additional, information on the data was extracted: the country with the largest sample size, the evolution of the number of papers, technologies, and theories used in the studies, and studies used in meta-analysis and weight analysis (Appendix A). Figure 2 illustrates the sum of all samples per country. 
During the period of our analysis (2001 to 2017), many journals (peer-reviewed) published different numbers of ISCI articles. Appendix B illustrates the number and evolution of articles that each journal published per year. However, between 2001 and 2010, the number of articles published was lower. The number began to grow from 2011 until 2017, and the expectation is to continue growing. The journals with more than ten publications are highlighted.

In the data extraction process, the original names of the independent and dependent variables from the studies were collected. In this process, we found variables with different names but deduced that they probably have a similar definition, e.g. perceived usefulness, usefulness, usefulness expectations; user satisfaction, overall satisfaction, satisfaction; confirmation, confirmation of expectations. In these circumstances, we chose the names of the most used variables in the literature, e.g. perceived usefulness, satisfaction, confirmation). More detailed information is presented in Appendix C.

\subsection{Moderator analysis}

Concerning moderators, we investigated some moderating effects in different relationships. To select the relationships, we used relationships that have enough observations (> 30) (Geyskens et al., 2009; Lipsey and Wilson, 2001). Regarding the moderator variables, we have selected different moderators suggested by the literature (Hofstede and Minkov, 2010; Santini et al., 2019b). For our study, we have used methodological, economic, and cultural moderators. This analysis is essential for the literature because it provides researchers a better understanding of the effects of the relationships and provides an overview of the potential moderators that can influence the continuance intention to use IS in future studies. Appendix D presents the moderators, the descriptions, and the coding structure. Sample size was analysed as a methodological moderator, considering that it plays a significant role in varying the effect sizes in the studies (Fern and Monroe, 1996). While a small sample size is more homogeneous, this aspect tends to overestimate the effect size of the relationships (Rosenthal and Rubin, 1982). We have also analysed moderators in the economic context, (1) economic development, and (2) innovation level. Economic 


\section{Findings}

\subsection{Meta-Analysis}

Table 1 represents the meta-analysis and weight analysis of the 60 relationships that were most often used, and which have occurred three or more times across the 115 studies. Columns 4 to 8 (meta-analysis information) of Table 1 present the number of times that a relationship was analysed (total), the sum of samples (sample), an average of the correlation coefficient (AVG of cc), normal standard deviation ( $\mathrm{Z}$ - value), and 95\% confidence interval. In addition, we then show the relationship between the dependent constructs and the independent constructs. Several dependent constructs relate to different independent constructs, such as continuance intention, which relates to 16 different independent constructs, followed by satisfaction, which applies to 14 different constructs and perceived usefulness, which applies to 7 different constructs.

The meta-analysis results reveal that the correlation coefficient of 60 relationships is statistically significant $(\mathrm{p}<0.01)$. The largest $\mathrm{Z}$-values are satisfaction on continuance intention (75.695), confirmation on perceived usefulness (55.921), confirmation on satisfaction (48.176), attitude on continuance intention (35.602), perceived usefulness on continuance intention (34.287), and perceived usefulness on satisfaction (33.995). 


\subsection{Weight analysis}

This method is used to estimate the importance of a predictor (i.e. independent construct) and predicts the strength of an independent construct (Jeyaraj et al., 2006). The weights of the 60 most used relationships were examined and are presented in columns 9 to 12 in Table 1.

The value of weight was computed by dividing the number of statistically significant relationships by the total number of studies used. When the weight is one (1), it shows that the relationship within the variables is significant in all the research, but if the weight is zero (0), it indicates that the relationship is not significant through all the studies examined (Jeyaraj et al., 2006).

\section{$<<$ Insert Table 1 here $>>$}

In order to identify the most effective predictors to use IS continuance intention, (Jeyaraj et al., 2006) classified independent variables in two ways: the variables that were evaluated 5 (five) or more times were classified as well-utilised, and the variables evaluated less than 5 (five) times seen as experimental. Additional definitions of Jeyaraj et al., (2006) have been taken into consideration : best predictors - are the relationships that were classified as well-utilised with the weight greater than or equal to 0.8 ; and promising predictors - relationships that were classified as experimental with the weight equal to 1 .

The outcomes of the 60 relationships assessed in the weight analysis show that 34 were classified as well-utilised, and 31 as best predictors (highlighted relationships) of the continuance intention to use an IS. Additionally, 24 out of 26 experimental relationships were classified as promising predictors, requiring more evaluation to succeed as best predictors. For future research, we encourage researchers to evaluate such promising predictors. However, in all the studies, no type of relationship was found to be not significant.

According to the findings of meta- and weight analyses, the most often used dependent variables were continuance intention, satisfaction, and perceived usefulness. Therefore, the most used independent variables to explain continuance intention (used more than ten times) were satisfaction, perceived usefulness, perceived enjoyment, attitude, and subjective norms. 

economic, and cultural context. Thus, these factors were tested in the relationships that predict continuance intention, and present a considerable number of observations (at least 30) (Geyskens et al., 2009; Lipsey and Wilson, 2001). However, the relationships selected were perceived usefulness and satisfaction to continuance intention (Schmidt and Hunter, 2016). The results of the analysis are presented in Table 2.

The moderator sample size had a significant moderating effect on the relationship of perceived usefulness to continuance intention $\left(\beta=0.338, \mathrm{M}_{\text {Low }}=0.418, \mathrm{M} \_\right.$High $\left.=0.316, \mathrm{p}<0.05\right)$, and had no significant moderating effect for the other relationships of satisfaction to continuance intention $\left(\beta=0.502, M_{\_}\right.$Low $=0.461, M_{\_}$High $\left.=0.448\right)$.

In the economic context, the moderator economic development had no significant moderating effect of perceived usefulness to continuance intention ( $\beta=0.467, M_{- \text {Low }}=0.364, \mathrm{M} \_$High $\left.=0.380\right)$, and satisfaction to continuance intention $\left(\beta=0.546, M_{\text {Low }}=0.451, M_{-H i g h}=0.466\right)$. Similarly, the moderator innovation level had no significant moderating effect of perceived usefulness to continuance intention $\left(\beta=0.490, M_{-} \_\right.$Low $\left.=0.330, M_{\text {High }}=0.414\right)$, and satisfaction to continuance intention $\left(\beta=0.491, M_{\_ \text {Low }}=0.492, M_{-}\right.$High $\left.=0.438\right)$.

In the cultural context, the power distance moderator had a significant moderating effect of satisfaction to continuance intention $\left(\beta=0.455, M_{-L o w}=0.495, M_{-H i g h}=0.414, p<0.05\right)$, and had no significant moderating effect on the other relationship of perceived usefulness to continuance intention $\left(\beta=0.497, M_{-}\right.$Low $=0.320, M_{-}$High $\left.=0.445\right)$. The moderator individualism had a significant moderating effect of perceived usefulness to continuance intention ( $\beta=0.499$, $\left.M_{\_ \text {Low }}=0.308, M_{\_ \text {High }}=0.420, p<0.1\right)$, and had no significant moderating effect on the other relationship, satisfaction to continuance intention $\left(\beta=0.526, M_{-}\right.$Low $=0.393$, M_High $\left.=0.449\right)$. The moderator masculinity had a significant moderating effect of satisfaction to continuance intention $\left(\beta=0.527, M_{\_}\right.$Low $\left.=0.374, M_{-H i g h}=0.465, p<0.1\right)$ and had no significant moderating effect on the other relationship of perceived usefulness to continuance intention ( $\beta=0.511, \mathrm{M} \_$Low $=0.336$, $M_{-}$High $\left.=0.435\right)$. The moderator uncertainty avoidance had a significant moderating effect on perceived usefulness to continuance intention $\left(\beta=0.361, M_{\_}\right.$Low $\left.=0.441, M_{-H i g h}=0.327, p<0.1\right)$, and had no significant moderating effect on the relationship satisfaction to continuance intention 
$\left(\beta=0.473, M_{\_}\right.$Low $\left.=0.433, M_{- \text {High }}=0.430\right)$. Similarly, the moderator long term orientation had a significant moderating effect on perceived usefulness to continuance intention $(\beta=0.332$, M_Low $=0.420, M_{-}$High $=0.308, \mathrm{p}<0.1$, and had no significant moderating effect on the relationship satisfaction to continuance intention $\left(\beta=0.540, \mathrm{M} \_\right.$Low $=0.453, \mathrm{M} \_$High $\left.=0.455\right)$. Finally, the moderator indulgence had a significant moderating effect on the relationship satisfaction to continuance intention $\left(\beta=0.584, M_{- \text {Low }}=0.425\right.$, $\mathrm{M} \_$High $\left._{1}=0.484, \mathrm{p}<0.1\right)$, and had no significant moderating effect on the relationship perceived usefulness to continuance intention $(\beta=0.394$, $\left.M_{\_ \text {Low }}=0.408, M_{\_ \text {High }}=0.343\right)$.

$<<$ Insert Table 2 here $>>$

\section{Discussion}

Considering the number of studies on continuance intention to use an IS using theories or models, it becomes significant and suitable to analyse and discuss their collective findings. We can verify that the variables and relationships used are quite dispersed, as studies are analysing different IS technologies, studies from separate times, and different geographical spaces with distinct cultures.

The results reveal that the meta- and weight analyses for the independent variables on equivalent dependent variables are closer. The higher the weight of an independent variable, the greater is the probability that it is significant in performing the meta-analysis (Rana et al., 2015). In the metaanalysis, all the 31 best predictors, and all the 24 promising predictors were found to be statistically significant. The remaining three well-utilised relationships, namely service quality on satisfaction, perceived ease of use on attitude, and perceived ease of use on continuance intention, were also statistically significant. The results reveal that the most important relationships to predict continuance intention to use an IS are simultaneously statistically significant in meta-analysis and best predictors in weight analysis.

Additionally, the width of the confidence interval depends on the correctness of individual studies along with the number of the cumulative studies (Rana et al., 2015). We can verify that all of the best predictor and promising predictor relationships obtained a narrow interval, providing confidence to the level of variance of the correlation values. 
According to the results, three theoretical models (Figure 3) were designed to support future studies on continuance intention to use an IS. The first model (A) was created using all the data from our analysis (general model), and then, to understand the model's evolution, the data were divided into two groups (from 2001 to 2010, and from 2011 to 2017), and with this information, two more models were created. The second model (B) was created using data from 2001 to 2010, and the last model (C) was created using data from 2011 to 2017. To generate the theoretical models, first, significant relationships from the meta-analysis were selected, second, the best predictors of weight analysis were selected, and finally, direct or indirect variables related to continuance intention to use an IS were selected. Moreover, the relationships such as service quality on satisfaction, perceived ease of use on attitude, and perceived ease of use on continuance intention were evaluated five or more times and with weight less than 0.8. Basically, because they were statistically non-significant in individual studies, future research is needed to prove or disapprove the existing trend (Jeyaraj et al., 2006).

According to the findings, it is possible to understand that there is an evolution of the models, just by comparing the original model of IS continuance intention (Bhattacherjee, 2001) with our general model. The general model is more complex and presents more relationships with a significant set of constructs. Going to model B, it is simpler than the general model (A). This facet means that, in that period (2001 to 2010), the key factors that influenced users to continue using IS were: satisfaction, perceived usefulness, and attitude. Continuance intention was used to predict continuance behaviour. In model B, Confirmation only explains satisfaction and perceived usefulness over time, and it starts explaining perceived ease of use and perceived enjoyment. This phenomenon also happened with perceived ease of use. It only explains satisfaction, over time, and explains perceived usefulness.

In model $\mathrm{C}$, which is more complex than model B and very similar to the general model (A), we can argue that in that period (2011 to 2017), (i) the type of IS increased considerably, then, to support this phenomenon, (ii) the number of constructs also increased. In model B, we have disconfirmation explaining satisfaction and perceived usefulness, but we do not have these relationships in model $\mathrm{C}$. This means that these relationships have been so well-explored that they became part of a collective body of knowledge. In model B, we have perceived ease of use explaining satisfaction; over time, the same construct started explaining perceived usefulness and 
began to be explained by confirmation. In model $\mathrm{C}$, we do not have continuance intention explaining continuance behaviour. From 2011 to 2017, it is possible to verify that the independent constructs increased significantly. Some constructs belong to other theoretical models, for example, attitude, subjective norms, and perceived behaviour control (Ajzen, 1985), system quality and information quality (DeLone and McLean, 1992) perceived ease of use (Davis, 1989). Two constructs do not appear in either model B or C but appear in the general model (A), such as performance and perceived behaviour control. This element means that these relationships have been explored over the whole range of our analysis (2001 - 2017). Moreover, when the dataset was divided, they did not become statistically significant in both groups.

However, over time, the theoretical models grow more complex, and new constructs appear, such as perceived enjoyment, trust, flow, subject norms, and performance, etc. Nevertheless, some constructs are in decadence because they turned into common knowledge, and some constructs like satisfaction, perceived usefulness, confirmation, perceived ease of use, and attitude remain over time. This characteristic means that these constructs are still essential to predict IS continuance intention. Now we can argue that we have a powerful model (A) to predict continuance intention to use IS, using distinct types of technologies, in different environments. In addition, the theoretical models had a significant evolution.

The dashed relationships mean that they were not statistically significant and best predictors in that period. Moreover, the performance and perceived behaviour control on continuance intention were statistically significant and best predictors only with all the dataset (model A).

$<<$ Insert Figure 3 here $>>$

We also found interesting results from the moderation analysis. In the methodology context, we found that the sample size has a moderating effect in the relationship of perceived usefulness to continuance intention. This outcome was not crucial to the relationship of satisfaction to continuance intention. The result showed that studies with low sample size have a strong relationship than studies with high sample size. This result confirms our assumption that a small sample has smaller effect variations in the studies (Fern and Monroe, 1996). 

al., 2019a). However, we consider these moderators important, considering that high economic and innovated countries tend to use more technologies (Kim and Peterson, 2017). Therefore, it is suggested that future studies use and test these moderators to bring new insights to the literature.

Concerning culture moderators, the moderator power distance had a significant moderating effect in the relationship satisfaction to continuance intention. Low power distance promoted a stronger effect than high power distance. This finding suggests that the people in this culture are more independent and accept that the power can be distributed unequally, therefore, influencing the satisfaction and continuance intention to use IS (Baptista and Oliveira, 2015; Hofstede and Minkov, 2010). The moderator individualism had a significant moderating effect in the relationship between perceived usefulness and continuance intention. The result showed that high level of individualism promotes a stronger relationship. This result highlights the fact that individualist people tend to have more perceptions of the usefulness of the systems, therefore, promoting continuance intention behaviour (Baptista and Oliveira, 2015; Hofstede, 1984).

The moderator masculinity had a significant moderating effect in the relationship between satisfaction and continuance intention. The result showed that a high level of masculinity promotes stronger relationships. This finding means that society has a high level of competitions to achieve success. Therefore, competitive people tend to use more technologies, acquire new skills, thus, promoting satisfaction and the intention to continue using IS (Hofstede and Minkov, 2010). The moderator uncertainty avoidance had a significant moderating effect in the relationship between perceived usefulness and continuance intention. The result showed that a low level of uncertainty avoidance promotes a stronger relationship. This finding is in accordance with another study (Baptista and Oliveira, 2015), suggesting that cultures that have a low level of uncertainty avoidance are more open to new technology, they improvise when necessary, tend to take risks, consequently, promoting continuance intention to use IS (Baptista and Oliveira, 2015). The moderator long term orientation had a significant moderating effect in the relationship perceived usefulness to continuance intention. The result presented that low levels of long-term orientation have a stronger influence on the relationship. This finding suggests that cultures with short term orientation tend to follow instructions, respect tradition, and focus on achieving quick results 
(Baptista and Oliveira, 2015). Finally, the moderator indulgence had a significant moderating effect in the relationship between satisfaction and continuance intention. The result revealed that a high level of indulgence promotes stronger relationships. This dimension means that people exhibit a willingness to fulfil their impulses and desires. Therefore, when they fulfil their desires, it is expected to promote satisfaction and continuance intention to use IS (Hofstede and Minkov, 2010).

\subsection{Theories, contexts, and technologies used in ISCI}

Studies on ISCI have used a wide range of theories such as the ECM (Bhattacherjee, 2001), expectation-confirmation theory (ECT) (Oliver, 1986), TAM (Davis, 1989), UTAUT (Venkatesh et al., 2003), Flow theory (Getzels and Csikszentmihalyi, 1978), to name a few. The results present that ECM was the most used theory, followed by TAM and ECT. Therefore, few studies used a single theory (Al-Debei et al., 2013; Chang and Zhu, 2012; Susanto et al., 2016), most of them integrated more than one theory in the context of ISCI (Chen et al., 2013; Gao et al., 2015; Hsiao et al., 2016). Additionally, the results show that some acceptance theories such as TAM and UTAUT were used in the context of ISCI (Belanche et al., 2014; Hadji and Degoulet, 2016; Joo et al., 2016; Wu and Chen, 2017). However, Bhattacherjee and Barfar, (2011) argued that it is not appropriate to use acceptance theories because it can generate misunderstandings and misapplications of the theories. We believe that instead of using traditional theories (TAM, TRA, ECT, etc.) we should import theories from other areas (e.g. psychology, medicine) and try new direct, indirect and moderation relationships, to present new results and insights (Bhattacherjee and Barfar, 2011; Nabavi et al., 2016). In the context of ISCI, ECM was the first theory proposed by (Bhattacherjee, 2001). ECM proposes that satisfaction to use IS is a crucial factor that impacts continuance intention, followed by perceived usefulness. Moreover, confirmation of expectations and perceived usefulness are important factors that influence user satisfaction. Most studies used ECM as a base theory. Some used ECM alone (Alraimi et al., 2015; Oghuma et al., 2016; Susanto et al., 2016) and others integrated with other theories and self-constructs (Chen et al., 2013; Lee, 2010; Limayem and Cheung, 2008). The results show that most studies have integrated more than one theory, so, we also agree with this practice, considering that it bestows new knowledge and enriches the theoretical models. 
In the technological context, the findings demonstrate that a wide variety of systems have been studied. Previous literature reviews have categorised the different types of technologies such as mobile information systems (MIS) (e.g. mobile instant messaging, mobile banking, mobile commerce), electronic business information systems (EBIS) (e.g. public e-services, online tourism services, Knowledge management systems), social information systems (SIS) (e.g. online communities, social networking services) and electronic learning information systems (ELIS) (e.g. e-learning, educational games, teaching blogs), to name a few (Nabavi et al., 2016; Shaikh and Karjaluoto, 2015). Of the 115 studies, most of them fall into the EBIS category (27\%), followed by SIS, MIS (26\%), and ELIS (21\%). Our findings are similar to those of Shaikh and Karjaluoto (2015), however, the SIS and MIS categories are booming, revealing a trend in recent years.

Regarding the region, the results are similar to previous literature reviews (Nabavi et al., 2016; Shaikh and Karjaluoto, 2015). The most studied regions were East Asia (e.g. Taiwan, China, Korea and Hong Kong), North America (e.g. USA), Europe (e.g. Spain, Germany, UK and France), Middle East (e.g. UAE, Kuwait), one in South America (Brazil) and Southeast Asia (The Philippines), however, no studies on ISCI were found in any African region (Nabavi et al., 2016; Shaikh and Karjaluoto, 2015).

\subsection{Implications for research}

The different studies have several implications for the literature. This research provides a complete image of all types of constructs, which were already studied in various subject areas on continuance intention to use IS. The findings from the meta-analysis and weight of the variables illustrated in this study aid researchers in making a careful selection of variables, contributing to future research (Hamari and Keronen, 2017). The results reveal that system quality, information quality, confirmation, disconfirmation, perceived ease of use, perceived usefulness, and perceived enjoyment are the most important constructs to influence satisfaction. The results further show that perceived ease of use can mediate the relationship between confirmation and satisfaction, and confirmation and perceived usefulness.

Additionally, perceived enjoyment can mediate the relationship between confirmation and satisfaction. Satisfaction can mediate the relationship between perceived enjoyment and continuance intention. Attitude can mediate the relationship between satisfaction and continuance 
intention. Affective commitment can mediate the relationship between utilitarian value, the hedonic value on continuance intention.

Moreover, the results show that there is a wide variety of constructs, coming from different theories and contexts, that can significantly influence continuance intention. These include affective commitment (Zhou et al., 2012, 2015), hedonic value (Hong et al., 2016a; Hong et al., 2016b), attitude (Hong et al., 2008; Liang et al., 2013), trust (Liao et al., 2006; Susanto et al., 2016), performance (Al-Debei et al., 2013; Chiu and Wang, 2008), habit (Liao et al., 2006; Limayem and Cheung, 2008), perceived behaviour control (Kim, 2010; Lee, 2010), flow (Chang and Zhu, 2012; Gao et al., 2015), and subjective norm (Bhattacherjee and Lin, 2014; Mouakket, 2015), thus, demonstrating that different theories and self-constructs can be integrated into the ISCI context. However, researchers can use our findings for future research, e.g. to those relationships that are statistically significant and have been classified as promising predictors (e.g. service quality on confirmation, performance on satisfaction, etc.) to become best predictors. Finally, the moderation analysis highlighted interesting results. The variables sample size, individualism, uncertainty avoidance, and long term orientation moderate the relationship between perceived usefulness and continuance intention. Furthermore, the variables power distance, masculinity, and indulgence moderate the relationship between satisfaction and continuance intention.

\subsection{Implications for practice}

The results of this paper have important practical implications. For practitioners, it is crucial to recognise the best predictors of continuance intention to use an IS, for better design and implementation of the IS, thus, ensuring long-term usage (Bhattacherjee, 2001; Shao, 2018; Yu et al., 2018). The best predictors such as system quality, information quality, and perceived ease of use on satisfaction, and perceived usefulness, perceived enjoyment, and satisfaction on continuance intention are relevant for practitioners. A practitioner should ensure the best implementation of IS for users, with proper infrastructure to use the system and information with quality to ensure user satisfaction (Zhao et al., 2018). Our results reveal that continuance intention to use an IS has been studied in different countries, with different cultures. Therefore, practitioners 
should have different managing strategies to ensure the satisfaction of the users and long-term usage of the IS (Zhang et al., 2012).

The results establish that system quality, information quality, perceived ease of use, perceived usefulness, perceived enjoyment, and confirmation of expectations are important factors to ensure user satisfaction. Thus, practitioners should ensure that the IS works, that users can perform an operation end-to-end, that the IS has no interruptions, that users navigate on the IS easily, that the information provided in the IS is useful, understandable and accurate, thus making the user realise the quality of the IS. Managers and decision-makers should provide all the necessary information, such as user guides, advertisements, flyers that explain the services and functionalities of the IS, to accelerate the understanding of the services. Managers should also provide IS that are interactive, easy to use, accessible, and fast. For instance, in the case of online banking, managers should be able to provide all the basic information such as short videos explaining how to use the system, guides, and functional helplines, to ensure that users will not face difficulties using the IS, thus, facilitating the interaction between the user and the IS. Users should realise all the benefits of the IS and be happy to use it. Our results indicate that different constructs can be used to influence continuance intention and show that different technologies were studied. However, managers must ensure that IS attract users, and make them feel part of the IS; for instance, by showing the user that he/she is vital to keep the IS. Advertise the best features or services to attract more users, through practical examples, show the user that the IS is pleasant, that it has a cheerful atmosphere, thus making the user feel pleasure and comfort when using it.

In some communities or companies, the responsible members, such as community leaders, managers, or directors are important people who influence other group of people. However, it is essential that IS managers identify these people and showcase the main benefits of the IS in order to influence others to use it, thereby increasing and attracting more users. The user needs to feel involved when using IS and be curious to use it more often. Thus, the use of IS should become automatic, so that whenever the user needs to fulfil a requirement, think of the IS first. Managers should ensure that users do not have difficulty using IS, by giving them control, resources, and the knowledge and ability to use it. The user should be attracted, in order to have the attitude to use the IS, enjoy using it, enjoy the idea of the IS, and feel comfortable using it. Thus, potential users will continue using the IS. 
Additionally, the results attest that the studies were conducted in different regions; in this sense, it is important to realise that communities have different habits and customs. For instance, the study of Chou et al., (2010) presents that in the context of continuance intention for knowledge creation in an online community, perceived identity verification is significant to influence performance expectancy in China (Baidu). However, it is not significant in Taiwan (Yahoo+). Ahmad and Sun, (2018) illustrate that in the context of continuance intention in social media mobile applications, social risk is significant to influence utilitarian value and hedonic value in Pakistan, but it is not in China. Therefore, practitioners should have different managing strategies, considering the region and therefore accommodate the habits, customs, satisfaction of the users and long-term usage of the IS (Zhang et al., 2012).

The results underscore that small sample size, high levels of individualism, low levels of uncertainty avoidance, and low levels of long-term orientation positively moderate the relationship between perceived usefulness and continuance intention. Regarding individualism, managers should focus on the task and autonomy of the individual. Individual management is more important than group management (Hofstede and Minkov, 2010). For uncertainty avoidance, the results are important for managers to promote the usability of the IS, considering that they are more receptive to new technology (Baptista and Oliveira, 2015). For long term orientation, the results are pivotal for managers because people with a low level of long-term orientation follow instructions, and respect rules and traditions. However, the results determine that a low level of power distance, a high level of masculinity, and a high level of indulgence positively moderate the relationship between satisfaction and continuance intention.

Concerning power distance, independence is a cardinal characteristic, and power should be distributed unequally (Baptista and Oliveira, 2015; Hofstede and Minkov, 2010). For masculinity, managers should promote competitions and training to motivate people. For indulgence, impulses and desires are more important. Managers should satisfy people according to their desires (Hofstede and Minkov, 2010).

\subsection{Limitations and recommendation}

The research contains several limitations. First, we did not include certain studies because of the unavailability of their quantitative data, or because they were qualitative. For example, some 
studies did not report the effect size when the relationships were statistically non-significant. Integrating these studies could generate relevant information in terms of the significance of the constructs. Secondly, in the previous research if the data are biased on IS continuance intention, then the effect of the mean presented through meta-analysis will also reflect this bias, and in this study, the handling publication biases are missing. Moreover, we used meta-essentials, a metaanalysis tool. This tool has limitations, considering that meta-essentials is not able to perform more advanced analyses, like linear model or structured equation model (Rhee et al., 2015), future research should consider a more advanced tool to provide more insights and a different approach to research.

Future research should consider relationships like service quality on confirmation, hedonic outcome expectation, and intrinsic motivation on continuance intention, satisfaction on habit, trust, hedonic benefits and performance on satisfaction as they were classified as promising predictors and were statistically significant with a high average correlation coefficient. Culture has an important impact on IS continuance intention, and future research should incorporate a culture variable such as subjective norms, habit or attitude, to provide additional insights. Considering that some IS such as mobile payments and gamification are growing exponentially, future research could contemplate a meta-analysis to synthesise and provide more findings in these subjects.

\section{Conclusions}

The goal of our research was to collect and analyse different studies on continuance intention to use IS, by using meta-analysis combined with weight analysis. The systematic review of existing studies comprised 115 papers, which constituted the basis for the analysis of our research. The most used technology was e-learning, followed by social network services. In the process of collecting data for our analysis, we found more than 600 relationships and selected the relationships that had been examined three or more times, totalling 60 different relationships. 34 out of the 60 most used relationships have been examined five or more times. We identified the most used variables in the literature and highlighted their relevance, contributing to the current state of the art (Hamari and Keronen, 2017; Wu et al., 2011; Zhao et al., 2018). 
Concerning moderation analysis, we presented noteworthy results. The relationship perceived usefulness to continuance intention was moderated with sample size, individualism, uncertainty avoidance and long term orientation. Furthermore, the relationship satisfaction to continuance intention was moderated with power distance, masculinity and indulgence. According to our empirical result, the evolution of the theoretical models was presented, using the best predictors and the significant relationships to predict continuance intention to use an IS. This study works as a reference basis for future research that seek to develop the area of continuance intention to use any type of IS. Moreover, among the most used constructs, we found constructs from the expectation confirmation model (Bhattacherjee, 2001), technology acceptance model (Davis, 1989), the theory of planned behaviour (Ajzen, 1985), and the DeLone and McLean IS success model (DeLone and McLean, 1992). According to Jeyaraj et al., (2006) criteria, 31 relationships were classified as best predictors (examined five or more times, and weight $\geq 0.8$ ), and 24 relationships were classified as promising predictors (examined fewer than five times, and weight $=1$ ), needing more tests to qualify as the best predictors. 


\section{References}

Abbas, H.A. and Hamdy, H.I. (2015), "Determinants of continuance intention factor in Kuwait communication market: Case study of Zain-Kuwait", Computers in Human Behavior, Vol. 49, pp. 648-657.

Ahmad, W. and Sun, J. (2018), "Antecedents of SMMA continuance intention in two culturally diverse countries: An empirical examination”, Journal of Global Information Technology Management, Routledge, Vol. 21 No. 1, pp. 45-68.

Ajzen, I. (1985), "From intentions to actions: A theory of planned behavior", Action Control, pp. $11-39$.

Al-Debei, M.M., Al-Lozi, E. and Papazafeiropoulou, A. (2013), "Why people keep coming back to Facebook: Explaining and predicting continuance participation from an extended theory of planned behaviour perspective", Decision Support Systems, Vol. 55 No. 1, pp. 43-54.

Albuquerque, J.P. de, Diniz, E.H. and Cernev, A.K. (2016), "Mobile payments: a scoping study of the literature and issues for future research", Information Development, Vol. 32 No. 3, pp. 527-553.

Alraimi, K.M., Zo, H. and Ciganek, A.P. (2015), "Understanding the MOOCs continuance: The role of openness and reputation", Computers and Education, Vol. 80, pp. 28-38.

Amoroso, D. and Lim, R. (2017), "The mediating effects of habit on continuance intention", International Journal of Information Management, Vol. 37 No. 6, pp. 693-702.

Baptista, G. and Oliveira, T. (2015), "Understanding mobile banking: The unified theory of acceptance and use of technology combined with cultural moderators", Computers in Human Behavior, Vol. 50, pp. 418-430.

Baptista, G. and Oliveira, T. (2016), "A weight and a meta-analysis on mobile banking acceptance research”, Computers in Human Behavior, Vol. 63, pp. 480-489.

Barnes, S. and Böhringer, M. (2011), "Modeling use continuance behaviour in microblogging services: The case of twitter", Journal of Computer Information Systems, Vol. 51 No. 4, pp. $1-10$.

Barnes, S.J. (2011), "Understanding use continuance in virtual worlds: Empirical test of a research model”, Information and Management, Vol. 48 No. 8, pp. 313-319.

Bayramusta, M. and Nasir, V.A. (2016), “A fad or future of IT?: A comprehensive literature review on the cloud computing research", International Journal of Information Management, Vol. 36 No. 4, pp. 635-644.

Belanche, D., Casaló, L. V., Flavián, C. and Schepers, J. (2014), “Trust transfer in the continued usage of public e-services", Information and Management, Vol. 51 No. 6, pp. 627-640.

Bhattacherjee, A. (2001), "Understanding information systems continuance: An expectation confirmation model”, MIS Quarterly, Vol. 25 No. 3, pp. 351-370.

Bhattacherjee, A. and Barfar, A. (2011), "Information Technology Continuance Research: Current State and Future Directions”, Asia Pacific Journal of Information Systems, Vol. 21 
No. 2, pp. 1-18.

Bhattacherjee, A. and Lin, C.-P. (2014), "A unified model of IT continuance: Three complementary perspectives and crossover effects", European Journal of Information Systems, Vol. 24 No. 4, pp. 1-10.

Bhattacherjee, A., Perols, J. and Sanford, C. (2008), "Information technology continuance: A theoretic extension and empirical test", Journal of Computer Information Systems, Vol. 49 No. 1, pp. 17-26.

Bhattacherjee, A. and Premkumar, G. (2004), "Understanding changes in belief and attitude toward information technology usage: A theoretical model and longitudinal test", MIS Quaterly, Vol. 28 No. 2, pp. 229-254.

Bøe, T., Gulbrandsen, B. and Sørebø, O. (2015), "How to stimulate the continued use of ICT in higher education: Integrating information systems continuance theory and agency theory", Computers in Human Behavior, Vol. 50, pp. 375-384.

Budiardjo, E.K., Pamenan, G., Hidayanto, A.N., Meyliana and Cofriyanti, E. (2017), “The impact of knowledge management system quality on the usage continuity and recommendation intention", Knowledge Management \& E-Learning, Vol. 9 No. 2, pp. 200 224.

Budner, P., Fischer, M., Rosenkranz, C., Basten, D. and Terlecki, L. (2017), "Information system continuance intention in the context of network effects and freemium business models: A replication study of cloud services in Germany", AIS Transactions on Replication Research, Vol. 3 No. December, pp. 1-13.

Carillo, K., Scornavacca, E. and Za, S. (2015), "The role of media dependency in predicting continuance intention to use ubiquitous media systems", Information and Management, Vol. 54 No. 3, pp. 317-335.

Carillo, K., Scornavacca, E. and Za, S. (2017), "The role of media dependency in predicting continuance intention to use ubiquitous media systems", Information and Management, Elsevier B.V., Vol. 54 No. 3, pp. 317-335.

Chang, I.-C., Liu, C.-C. and Chen, K. (2014), "The effects of hedonic/utilitarian expectations and social influence on continuance intention to play online games", Internet Research, Vol. 24 No. 1, pp. 21-45.

Chang, Y.P. and Zhu, D.H. (2012), "The role of perceived social capital and flow experience in building users' continuance intention to social networking sites in China", Computers in Human Behavior, Vol. 28 No. 3, pp. 995-1001.

Chen, C.P., Lai, H.M. and Ho, C.Y. (2015), "Why do teachers continue to use teaching blogs? the roles of perceived voluntariness and habit", Computers and Education, Elsevier Ltd, Vol. 82 No. 1, pp. 236-249.

Chen, I.Y.L. (2007), “The factors influencing members' continuance intentions in professional virtual communities a longitudinal study", Journal of Information Science, Vol. 33 No. 4, pp. 451-467. 
Chen, S.-C., Chen, H.-H. and Chen, M. (2009), "Determinants of satisfaction and continuance intention towards self-service technologies", Industrial Management \& Data Systems, Vol. 109 No. 9, pp. 1248-1263.

Chen, S.-C., Liu, M.-L. and Lin, C.-P. (2013), “Integrating technology readiness into the expectation-confirmation model: An empirical study of mobile services", Cyberpsychology, Behavior, and Social Networking, Vol. 16 No. 8, pp. 604-612.

Chen, S.C. (2012), "To use or not to use: understanding the factors affecting continuance intention of mobile banking", International Journal of Mobile Communications, Vol. 10 No. 5, pp. 490-507.

Chen, S.C., Yen, D.C. and Hwang, M.I. (2012), "Factors influencing the continuance intention to the usage of Web 2.0: An empirical study", Computers in Human Behavior, Vol. 28 No. 3 , pp. 933-941.

Cheung, C.M.K., Lee, M.K.O. and Lee, Z.W.Y. (2013), "Understanding the continuance intention of knowledge sharing in online communities of practice through the postknowledge-sharing evaluation processes", Journal of the American Society for Information Science and Technology, Vol. 64 No. 7, pp. 1357-1374.

Chiu, C.-M., Hsu, M.-H., Sun, S.-Y., Lin, T.-C. and Sun, P.-C. (2005), "Usability, quality, value and e-learning continuance decisions", Computers \& Education, Vol. 45 No. 4, pp. 399416.

Chiu, C.M., Chiu, C.S. and Chang, H.C. (2007), "Examining the integrated influence of fairness and quality on learners' satisfaction and Web-based learning continuance intention", Information Systems Journal, Vol. 17 No. 3, pp. 271-287.

Chiu, C.M., Sun, S.Y., Sun, P.C. and Ju, T.L. (2007), “An empirical analysis of the antecedents of web-based learning continuance", Computers and Education, Vol. 49 No. 4, pp. 12241245 .

Chiu, C.M. and Wang, E.T.G. (2008), "Understanding Web-based learning continuance intention: The role of subjective task value", Information and Management, Vol. 45 No. 3, pp. 194-201.

Cho, J. (2016), "The impact of post-adoption beliefs on the continued use of health apps", International Journal of Medical Informatics, Vol. 87, pp. 75-83.

Choi, N. and Joo, S. (2016), "Booklovers' world: An examination of factors affecting continued usage of social cataloging sites", Journal of the Association for Information Science and Technology, Vol. 67 No. 12, pp. 3022-3035.

Choi, S. (2016), “The flipside of ubiquitous connectivity enabled by smartphone-based social networking service: Social presence and privacy concern", Computers in Human Behavior, Vol. 65, pp. 325-333.

Chong, A.Y.-L. (2015), "Understanding mobile commerce continuance intentions: An empirical analysis of Chinese consumers", Journal of Computer Information Systems, Vol. 53 No. 4, pp. $22-30$. 
Chou, S.-W., Min, H.-T., Chang, Y.-C. and Lin, C.-T. (2010), "Understanding continuance intention of knowledge creation using extended expectation-confirmation theory: an empirical study of Taiwan and China online communities", Behaviour \& Information Technology, Vol. 29 No. 6, pp. 557-570.

Dathan, G. and Akkoyunlu, B. (2016), "Modeling the continuance usage intention of online learning environments", Computers in Human Behavior, Vol. 60, pp. 198-211.

Davis, F.D. (1989), "Perceived Usefulness, Perceived Ease of Use, and User Acceptance of Information Technology”, MIS Quarterly, Vol. 13 No. 3, pp. 319-340.

DeLone, W.H. and McLean, E.R. (1992), "Information Systems Success: The Quest for the dependent variable", Information Systems Research, Vol. 3 No. 1, pp. 60-95.

Fern, E.F. and Monroe, K.B. (1996), "Effect-size estimates: Issues and problems in interpretation", Journal of Consumer Research, Vol. 23 No. 2, p. 89.

Fettke, P. (2006), "State-of-the-art des state-of-the-art", Wirtschaftsinformatik, Vol. 48 No. 4, pp. 257-266.

French, A.M., Luo, X.R. and Bose, R. (2017), "Toward a holistic understanding of continued use of social networking tourism: A mixed-methods approach", Information and Management, Vol. 54 No. 6, pp. 802-813.

Frohberg, D., Göth, C. and Schwabe, G. (2009), "Mobile learning projects - a critical analysis of the state of the art", Journal of Computer Assisted Learning, Vol. 25 No. 4, pp. 307-331.

Gallego, M.D., Bueno, S. and Noyes, J. (2016), "Second Life adoption in education: A motivational model based on Uses and Gratifications theory", Computers and Education, Vol. 100, pp. 81-93.

Gao, L., Waechter, K.A. and Bai, X. (2015), "Understanding consumers' continuance intention towards mobile purchase: A theoretical framework and empirical study - A case of China", Computers in Human Behavior, Vol. 53, pp. 249-262.

Gerow, J.E., Grover, V., Thatcher, J. and Roth, P.L. (2014), "Looking Toward the Future of ITBusiness Strategic Alignment through the Past: A Meta-Analysis", MIS Quarterly, Vol. 38 No. 4, pp. 1059-1085.

Getzels, J.W. and Csikszentmihalyi, M. (1978), "A longitudinal study of problem finding in art", The American Journal of Psychology, Vol. 91 No. 1, pp. 165-169.

Geyskens, I., Krishnan, R., Steenkamp, J.B.E.M. and Cunha, P. V. (2009), “A review and evaluation of meta-analysis practices in management research", Journal of Management, Vol. 35 No. 2, pp. 393-419.

Hadji, B. and Degoulet, P. (2016), "Information system end-user satisfaction and continuance intention: A unified modeling approach", Journal of Biomedical Informatics, Vol. 61, pp. 185-193.

Hamari, J. and Keronen, L. (2017), "Why do people play games? A meta-analysis", International Journal of Information Management, Vol. 37 No. 3, pp. 125-141. 


\section{Hofstede, G. (1984), Culture's Consequences: International Differences in Work-Related} Values, Vol. 5, sage.

Hofstede, G. and Minkov, M. (2010), "Long- versus short-term orientation: New perspectives", Asia Pacific Business Review, Vol. 16 No. 4, pp. 493-504.

Hong, J.C., Hwang, M.Y., Hsu, C.H., Tai, K.H. and Kuo, Y.C. (2015), "Belief in dangerous virtual communities as a predictor of continuance intention mediated by general and online social anxiety: The Facebook perspective", Computers in Human Behavior, Vol. 48, pp. 663-670.

Hong, J.C., Hwang, M.Y., Tai, K.H. and Kuo, Y.C. (2016a), "Crystallized intelligence affects hedonic and epistemic values to continue playing a game with saliency-based design", Computers and Education, Vol. 95, pp. 75-84.

Hong, J.C., Lin, P.H. and Hsieh, P.C. (2017a), "The effect of consumer innovativeness on perceived value and continuance intention to use smartwatch", Computers in Human Behavior, Vol. 67, pp. 264-272.

Hong, J.C., Tai, K.H., Hwang, M.Y., Kuo, Y.C. and Chen, J.S. (2017b), "Internet cognitive failure relevant to users' satisfaction with content and interface design to reflect continuance intention to use a government e-learning system", Computers in Human Behavior, Vol. 66, pp. 353-362.

Hong, J.C., Tsai, C.R., Fan-Chiang, C. and Hwang, M.Y. (2016b), "Mindfulness in learning safe sex via social media: Perspectives of personality and experiential value", Computers in Human Behavior, Vol. 64, pp. 337-346.

Hong, S., Kim, J. and Lee, H. (2008), "Antecedents of use-continuance in information systems: Toward an inegrative view", Journal of Computer Information Systems, Vol. 48 No. 3, pp. $61-73$.

Hsiao, C.C. and Chiou, J.S. (2012), "The impact of online community position on online game continuance intention: Do game knowledge and community size matter?", Information and Management, Vol. 49 No. 6, pp. 292-300.

Hsiao, C.H., Chang, J.J. and Tang, K.Y. (2016), "Exploring the influential factors in continuance usage of mobile social Apps: Satisfaction, habit, and customer value perspectives", Telematics and Informatics, Vol. 33 No. 2, pp. 342-355.

Hsiao, W.-H. and Chang, T.-S. (2014), "Understanding consumers' continuance intention towards mobile advertising: a theoretical framework and empirical study", Behaviour \& Information Technology, Vol. 33 No. 7, pp. 730-742.

Hsu, M.-H. and Chiu, C.-M. (2004), "Predicting electronic service continuance with a decomposed theory of planned behaviour", Behaviour \& Information Technology, Vol. 23 No. 5, pp. 359-373.

Hsu, M.-H., Yen, C.-H., Chiu, C.-M. and Chang, C.-M. (2006), “A longitudinal investigation of continued online shopping behavior: An extension of the theory of planned behavior", International Journal of Human-Computer Studies, Vol. 64 No. 9, pp. 889-904. 
Huang, H.Y. (2016), "Examining the beneficial effects of individual's self-disclosure on the social network site", Computers in Human Behavior, Vol. 57, pp. 122-132.

Ifinedo, P. (2017), 'Examining students' intention to continue using blogs for learning: Perspectives from technology acceptance, motivational, and social-cognitive frameworks", Computers in Human Behavior, Vol. 72, pp. 189-199.

Jeyaraj, A., Rottman, J.W. and Lacity, M.C. (2006), “A review of the predictors, linkages, and biases in IT innovation adoption research", Journal of Information Technology, Vol. 21 No. 1, pp. 1-23.

Jin, X.L., Lee, M.K.O. and Cheung, C.M.K. (2010), "Predicting continuance in online communities: Model development and empirical test", Behaviour and Information Technology, Vol. 29 No. 4, pp. 383-394.

Joo, Y.J., Kim, N. and Kim, N.H. (2016), "Factors predicting online university students' use of a mobile learning management system", Educational Technology Research and Development, Vol. 64 No. 4, pp. 611-630.

Joo, Y.J., So, H.J. and Kim, N.H. (2018), “Examination of relationships among students' selfdetermination, technology acceptance, satisfaction, and continuance intention to use KMOOCs", Computers and Education, Vol. 122 No. 01, pp. 260-272.

Kaewkitipong, L., Chen, C.C. and Ractham, P. (2016), "Using social media to enrich information systems field trip experiences: Students' satisfaction and continuance intentions", Computers in Human Behavior, Vol. 63, pp. 256-263.

Kang, S. (2014), "Factors influencing intention of mobile application use”, International Journal of Mobile Communications, Vol. 12 No. 4, pp. 360-379.

Kang, Y.J. and Lee, W.J. (2015), "Self-customization of online service environments by users and its effect on their continuance intention”, Service Business, Vol. 9 No. 2, pp. 321-342.

Kim, B. (2010), “An empirical investigation of mobile data service continuance: Incorporating the theory of planned behavior into the expectation-confirmation model", Expert Systems with Applications, Vol. 37 No. 10, pp. 7033-7039.

Kim, B. (2011), "Understanding antecedents of continuance intention in social-networking services.”, Cyberpsychology, Behavior and Social Networking, Vol. 14 No. 4, pp. 199-205.

Kim, G., Shin, B. and Lee, H.G. (2009), "Understanding dynamics between initial trust and usage intentions of mobile banking”, Information Systems Journal, Vol. 19 No. 3, pp. 283311.

Kim, Y. and Peterson, R.A. (2017), "A Meta-analysis of online trust relationships in Ecommerce”, Journal of Interactive Marketing, Vol. 38, pp. 44-54.

Krasnova, H., Veltri, N.F., Eling, N. and Buxmann, P. (2017), "Why men and women continue to use social networking sites: The role of gender differences", Journal of Strategic Information Systems, Vol. 26 No. 4, pp. 261-284.

Ku, E.C.S. and Chen, C.-D. (2015), “Cultivating travellers' revisit intention to e-tourism service: 
The moderating effect of website interactivity", Behaviour and Information Technology, Vol. 34 No. 5, pp. 465-478.

Lankton, N. and McKnight, H. (2012), "Examining two expectation disconfirmation theory models: Assimilation and asymmetry effects", Journal of the Association for Information Systems, Vol. 13 No. 2, pp. 88-115.

Larsen, T.J., Sørebø, A.M. and Sørebø, Ø. (2009), “The role of task-technology fit as users’ motivation to continue information system use", Computers in Human Behavior, Vol. 25 No. 3, pp. 778-784.

Laukkanen, T. (2007), "Internet vs mobile banking: comparing customer value perceptions", Business Process Management Journal, Vol. 13 No. 6, pp. 788-797.

Lee, I., Choi, B., Kim, J. and Hong, S.-J. (2007), “Culture-Technology Fit: Effects of Cultural Characteristics on the Post-Adoption Beliefs of Mobile Internet Users", International Journal of Electronic Commerce, Vol. 11 No. 4, pp. 11-51.

Lee, M.C. (2010), "Explaining and predicting users' continuance intention toward e-learning: An extension of the expectation-confirmation model", Computers and Education, Vol. 54 No. 2, pp. 506-516.

Lee, Y. and Kwon, O. (2011), "Intimacy, familiarity and continuance intention: An extended expectation-confirmation model in web-based services", Electronic Commerce Research and Applications, Vol. 10 No. 3, pp. 342-357.

Lehto, T. and Oinas-Kukkonen, H. (2015), "Explaining and predicting perceived effectiveness and use continuance intention of a behaviour change support system for weight loss", Behaviour \& Information Technology, Vol. 34 No. 2, pp. 176-189.

Liang, T.-P., Ling, Y.-L., Yeh, Y.-H. and Lin, B. (2013), “Contextual factors and continuance intention of mobile services", International Journal of Mobile Communications, Vol. 11 No. 4, pp. 313-329.

Liao, C., Palvia, P. and Lin, H.-N. (2006), "The roles of habit and website quality in ecommerce", International Journal of Information Management, Vol. 26 No. 6, pp. 469-483.

Liao, Z. and Shi, X. (2017), "Web functionality, web content, information security, and online tourism service continuance", Journal of Retailing and Consumer Services, Vol. 39, pp. 258-263.

Limayem, M. and Cheung, C.M.K. (2008), "Understanding information systems continuance: The case of Internet-based learning technologies", Information and Management, Vol. 45 No. 4, pp. 227-232.

Limayem, M. and Cheung, C.M.K. (2011), "Predicting the continued use of Internet-based learning technologies: the role of habit", Behaviour \& Information Technology, Vol. 30 No. 1, pp. 91-99.

Limayem, M., Hirt, S.G. and Cheung, C.M.K. (2007), "How habit limits the predictive power of intention: The case of information systems continuance", MIS Quarterly, Vol. 31 No. 4, pp. 705-737. 
Lin, C.P. and Bhattacherjee, A. (2010), "Extending technology usage models to interactive hedonic technologies: A theoretical model and empirical test", Information Systems Journal, Vol. 20 No. 2, pp. 163-181.

Lin, H., Fan, W. and Chau, P.Y.K. (2014), “Determinants of users' continuance of social networking sites: A self-regulation perspective", Information and Management, Vol. 51 No. 5, pp. 595-603.

Lin, K.-M. (2016), “Understanding undergraduates' problems from determinants of Facebook continuance intention”, Behaviour \& Information Technology, Vol. 35 No. 9, pp. 693-705.

Lin, K.M. (2011), "E-Learning continuance intention: Moderating effects of user e-learning experience", Computers and Education, Vol. 56 No. 2, pp. 515-526.

Lin, K.M., Chen, N.S. and Fang, K. (2011), "Understanding e-learning continuance intention: A negative critical incidents perspective", Behaviour and Information Technology, Vol. 30 No. 1, pp. 77-89.

Lin, X., Featherman, M. and Sarker, S. (2017), “Understanding factors affecting users' social networking site continuance: A gender difference perspective", Information and Management, Vol. 54 No. 3, pp. 383-395.

Lipsey, M. and Wilson, D. (2001), "Practical Meta-analysis", Centers for Teaching and Technology - Book Library, Vol. 49.

Lowry, P.B., Gaskin, J.E. and Moody, G.D. (2015), "Proposing the multimotive information systems continuance model ( MISC ) to better explain end-user system evaluations and continuance intentions", Journal of the Association for Information, Vol. 16 No. 7, pp. 515579.

Lu, H.-P. and Lee, M.-R. (2011), "Experience differences and continuance intention of blog sharing", Behaviour \& Information Technology, Vol. 31 No. 11, pp. 1-15.

Lu, J., Liu, C. and Wei, J. (2017), "How important are enjoyment and mobility for mobile applications?”, Journal of Computer Information Systems, Vol. 57 No. 1, pp. 1-12.

Mohammadyari, S. and Singh, H. (2015), "Understanding the effect of e-learning on individual performance: The role of digital literacy”, Computers \& Education, Vol. 82, pp. 11-25.

Mouakket, S. (2015), "Factors influencing continuance intention to use social network sites: The Facebook case", Computers in Human Behavior, Vol. 53, pp. 102-110.

Mouakket, S. (2018), “The role of personality traits in motivating users' continuance intention towards Facebook: Gender differences", Journal of High Technology Management Research, Vol. 29 No. 1, pp. 124-140.

Nabavi, A., Taghavi-Fard, M.T., Hanafizadeh, P. and Taghva, M.R. (2016), "Information Technology Continuance Intention: A Systematic Literature Review", International Journal of E-Business Research, Vol. 12 No. 1, pp. 58-95.

Oghuma, A.P., Libaque-Saenz, C.F., Wong, S.F. and Chang, Y. (2016), “An expectationconfirmation model of continuance intention to use mobile instant messaging", Telematics 
and Informatics, Vol. 33 No. 1, pp. 34-47.

Oliver, R.L. (1986), “A Cognitive Model of the Antecedents and Consequences of Satisfaction Decisions", Journal of Marketing Research, Vol. 17 No. 4, pp. 460-469.

Pereira, F.A. de M., Ramos, A.S.M., Andrade, A.P.V. de and Oliveira, B.M.K. de. (2015), "Continued usage of e-learning: Expectations and performance", Journal of Information Systems and Technology Management, scielo.

Premkumar, G. and Bhattacherjee, A. (2008), "Explaining information technology usage: A test of competing models", Omega, Vol. 36 No. 1, pp. 64-75.

Rana, N.P., Dwivedi, Y.K. and Williams, M.D. (2015), “A meta-analysis of existing research on citizen adoption of e-government", Information Systems Frontiers, Vol. 17 No. 3, pp. 547563.

Rhee, H. van, Suurmond, R. and Hak, T. (2015), "User manual for meta-essentials: Workbooks for meta-analyses", The Netherlands: Erasmus Research Institute of Management, pp. 1-49.

Roca, J.C., Chiu, C.M. and Martínez, F.J. (2006), "Understanding e-learning continuance intention: An extension of the Technology Acceptance Model", International Journal of Human Computer Studies, Vol. 64 No. 8, pp. 683-696.

Rosenthal, R. and Rubin, D.B. (1982), "A simple, general purpose display of magnitude of experimental effect", Journal of Educational Psychology, Vol. 74 No. 2, pp. 166-169.

Sällberg, H. and Bengtsson, L. (2016), "Computer and smartphone continuance intention: A motivational model”, Journal of Computer Information Systems, Vol. 56 No. 4, pp. 321330 .

Santini, F. de O., Ladeira, W.J., Sampaio, C.H., Perin, M.G. and Dolci, P.C. (2019a), "Propensity for technological adoption: an analysis of effects size in the banking sector", Behaviour and Information Technology, pp. 1-15.

Santini, F.D.O., Ladeira, W.J., Sampaio, C.H., Perin, M.G. and Dolci, P.C. (2019b), “A metaanalytical study of technological acceptance in banking contexts", International Journal of Bank Marketing, Vol. 37 No. 3, pp. 755-774.

Schmidt., F.L. and Hunter, J.E. (2004), Methods of Meta-Analysis: Correcting Error and Bias in Research Findings, Sage.

Schmidt, F.L. and Hunter, J.E. (2016), Methods of Meta-Analysis: Correcting Error and Bias in Research Findings, Sage.

Seol, S., Lee, H., Yu, J. and Zo, H. (2016), "Continuance usage of corporate SNS pages: A communicative ecology perspective", Information \& Management, Vol. 53 No. 6, pp. 740751.

Shaikh, A.A. and Karjaluoto, H. (2015), "Making the most of information technology \& systems usage: A literature review, framework and future research agenda", Computers in Human Behavior, Vol. 49, pp. 541-566.

Shao, Z. (2018), "Examining the impact mechanism of social psychological motivations on 
individuals' continuance intention of MOOCs-The moderating effect of gender", Internet Research, Vol. 28 No. 1, pp. 232-250.

Shin, D.H. and Biocca, F. (2017), "Health experience model of personal informatics: The case of a quantified self", Computers in Human Behavior, Vol. 69, pp. 62-74.

Song, J., Kim, J. and Cho, K. (2017), 'Understanding users' continuance intentions to use smartconnected sports products", Sport Management Review, Vol. 21 No. 5, pp. 477-490.

Sørebø, Ø., Halvari, H., Gulli, V.F. and Kristiansen, R. (2009), “The role of self-determination theory in explaining teachers' motivation to continue to use e-learning technology", Computers and Education, Vol. 53 No. 4, pp. 1177-1187.

Steelman, Z.R. and Soror, A.A. (2017), "Why do you keep doing that? The biasing effects of mental states on IT continued usage intentions", Computers in Human Behavior, Vol. 73, pp. 209-223.

Šumak, B., Heričko, M. and Pušnik, M. (2011), “A meta-analysis of e-learning technology acceptance: The role of user types and e-learning technology types", Computers in Human Behavior, Vol. 27 No. 6, pp. 2067-2077.

Sun, Y. and Mouakket, S. (2015), "Assessing the impact of enterprise systems technological characteristics on user continuance behavior: An empirical study in China", Computers in Industry, Vol. 70, pp. 153-167.

Susanto, A., Chang, Y. and Ha, Y. (2016), "Determinants of continuance intention to use the smartphone banking services", Industrial Management \& Data Systems, Vol. 116 No. 3, pp. $508-525$.

Vedadi, A. and Warkentin, M. (2016), "Continuance intention on using mobile banking applications - A replication study of information systems continuance model”, AIS Transactions on Replication Research, Vol. 2, pp. 1-11.

Venkatesh, V., Morris, M., Davis, G. and Davis, F. (2003), "User acceptance of information technology: toward a unified view”, MIS Quarterly, Vol. 27 No. 3, pp. 425-478.

Wang, K. (2015), "Determinants of mobile value-added service continuance: The mediating role of service experience", Information and Management, Vol. 52 No. 3, pp. 261-274.

Warkentin, M., Johnston, A.C., Shropshire, J. and Barnett, W.D. (2016), “Continuance of protective security behavior: A longitudinal study", Decision Support Systems, Vol. 92, pp. $25-35$.

Wood, J.A. (2007), "Methodology for Dealing With Duplicate Study Effects in a MetaAnalysis”, Organizational Research Methods, Vol. 11 No. 1, pp. 79-95.

Wu, B. and Chen, X. (2017), "Continuance intention to use MOOCs: Integrating the technology acceptance model (TAM) and task technology fit (TTF) model”, Computers in Human Behavior, Vol. 67, pp. 221-232.

Wu, K., Zhao, Y., Zhu, Q., Tan, X. and Zheng, H. (2011), “A meta-analysis of the impact of trust on technology acceptance model: Investigation of moderating influence of subject and 
context type", International Journal of Information Management, Vol. 31 No. 6, pp. $572-$ 581.

Yang, H.L. and Lin, R.X. (2017), "Determinants of the intention to continue use of SoLoMo services: Consumption values and the moderating effects of overloads", Computers in Human Behavior, Vol. 73, pp. 583-595.

Yoon, C. and Rolland, E. (2015), "Understanding continuace use in social networking services", Journal of Computer Information Systems, Vol. 55 No. 2, pp. 1-8.

Yu, L., Cao, X., Liu, Z., Gong, M. and Adeel, L. (2018), “Understanding mobile payment users' continuance intention: a trust transfer perspective", Internet Research, Vol. 28 No. 2, pp. $456-476$.

Zarantonello, L., Jedidi, K. and Schmitt, B.H. (2013), "Functional and experiential routes to persuasion: An analysis of advertising in emerging versus developed markets", International Journal of Research in Marketing, Vol. 30 No. 1, pp. 46-56.

Zhang, C.B., Li, Y.N., Wu, B. and Li, D.J. (2017), "How WeChat can retain users: Roles of network externalities, social interaction ties, and perceived values in building continuance intention", Computers in Human Behavior, Vol. 69, pp. 284-293.

Zhang, L., Zhu, J. and Liu, Q. (2012), “A meta-analysis of mobile commerce adoption and the moderating effect of culture", Computers in Human Behavior, Vol. 28 No. 5, pp. 19021911.

Zhang, X., Yan, X., Cao, X., Sun, Y., Chen, H. and She, J. (2017), "The role of perceived ehealth literacy in users' continuance intention to use mobile healthcare applications: an exploratory empirical study in China”, Information Technology for Development, Vol. 24 No. 2, pp. 198-223.

Zhao, L. and Lu, Y. (2012), "Enhancing perceived interactivity through network externalities: An empirical study on micro-blogging service satisfaction and continuance intention", Decision Support Systems, Vol. 53 No. 4, pp. 825-834.

Zhao, L., Lu, Y., Zhang, L. and Chau, P.Y.K. (2012), “Assessing the effects of service quality and justice on customer satisfaction and the continuance intention of mobile value-added services: An empirical test of a multidimensional model”, Decision Support Systems, Vol. 52 No. 3, pp. 645-656.

Zhao, Y., Ni, Q. and Zhou, R. (2018), "What factors influence the mobile health service adoption? A meta-analysis and the moderating role of age", International Journal of Information Management, Vol. 43, pp. 342-350.

Zheng, L. (2019), "The role of consumption emotions in users' mobile gaming application continuance intention", Information Technology and People, Vol. 33 No. 1, pp. 340-360.

Zhong, Z., Luo, J. and Zhang, M. (2015), "Understanding antecedents of continuance intention in mobile travel booking service", International Journal of Business and Management, Vol. 10 No. 9, pp. 156-163.

Zhou, T. (2011), “An empirical examination of users' post-adoption behaviour of mobile 
services", Behaviour \& Information Technology, Vol. 30 No. 2, pp. 241-250.

Zhou, T. and Li, H. (2014), "Understanding mobile SNS continuance usage in China from the perspectives of social influence and privacy concern", Computers in Human Behavior, Vol. 37, pp. 283-289.

Zhou, Z., Fang, Y., Vogel, D.R., Jin, X.-L. and X. (2012), “Attracted to or locked in? Predicting continuance intention in social virtual world services", Journal of Management Information Systems, Vol. 29 No. 1, pp. 273-306.

Zhou, Z., Jin, X.-L., Fang, Y. and Vogel, D. (2015), “Toward a theory of perceived benefits, affective commitment, and continuance intention in social virtual worlds: cultural values (indulgence and individualism) matter", European Journal of Information Systems, Nature Publishing Group, Vol. 24 No. 3, pp. 247-261.

Zhou, Z., Jin, X.L. and Fang, Y. (2014), "Moderating role of gender in the relationships between perceived benefits and satisfaction in social virtual world continuance", Decision Support Systems, Vol. 65, pp. 69-79.

Zolotov, M.N., Oliveira, T. and Casteleyn, S. (2018), "E-participation adoption models research in the last 17 years: A weight and meta-analytical review", Computers in Human Behavior, Vol. 81, pp. 350-365. 


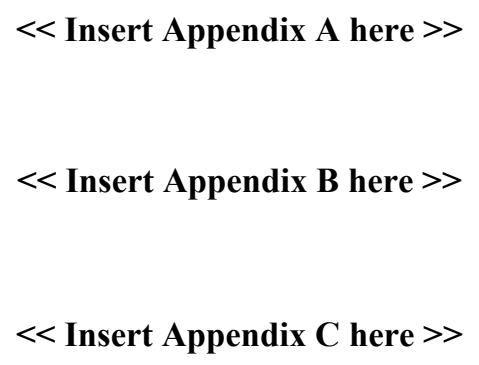




\section{A meta-analysis of the quantitative studies in continuance intention to use an information system}

\section{Highlights}

- Meta-analysis and weight analysis were used to obtains the findings.

- The most important predictors of continuance intention to use IS are presented.

- A temporal analysis of the theoretical models is presented.

- The evolution of the constructs over time is presented.

- A moderation analysis is presented. 
1. Keywords selection for the research.

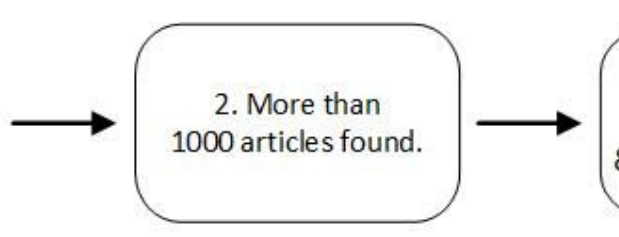

3. Articles related to IS, that present a theoretical model $\&$ quantitative data were selected.

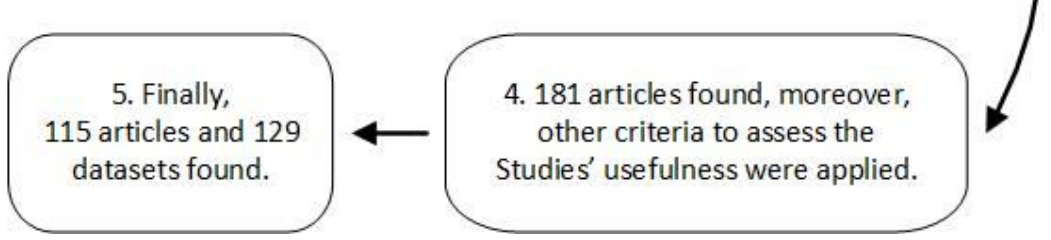

Figure 1 - Process to select articles for our research.

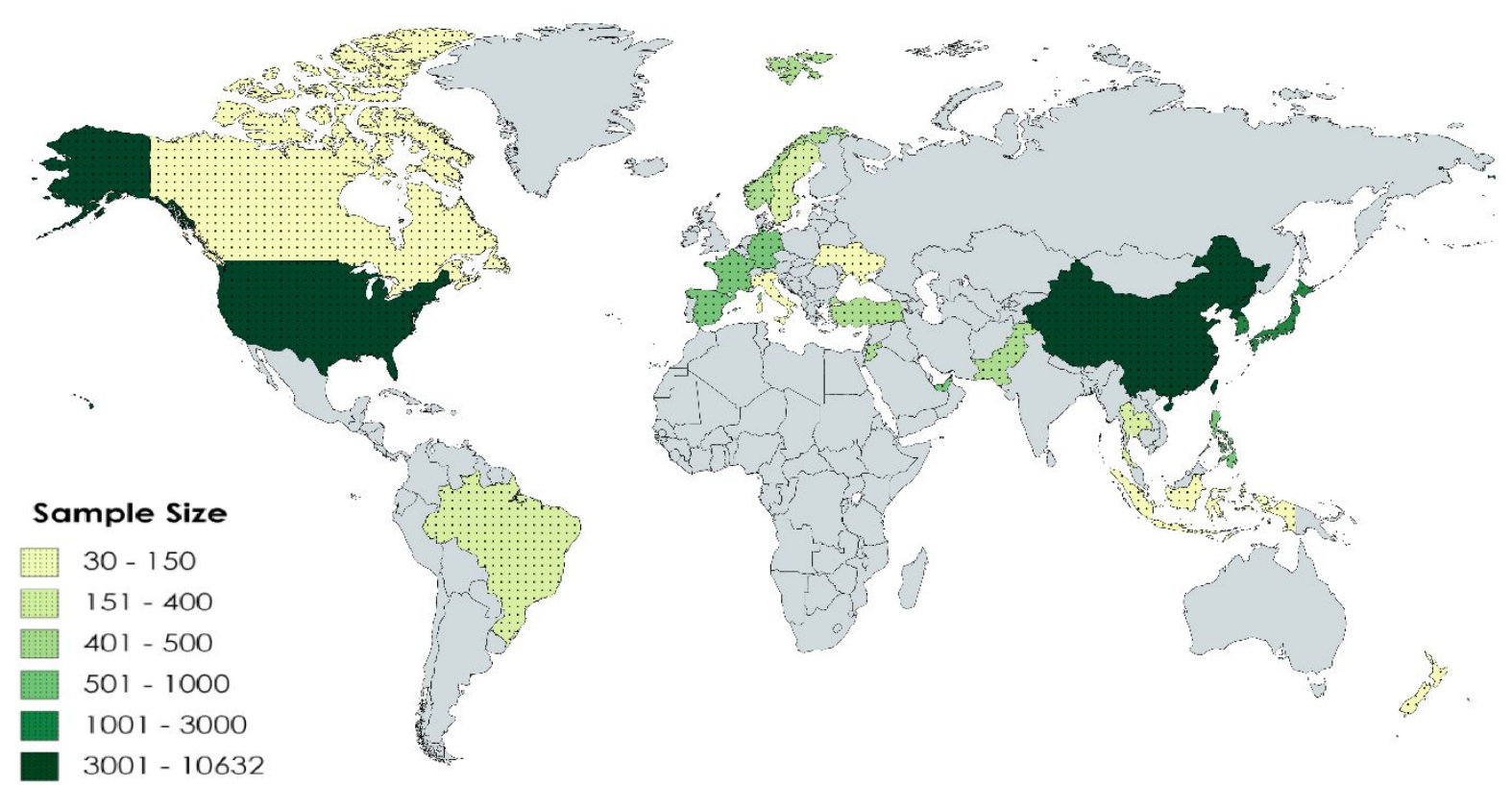

Figure 2 - Countries and sample size used in studies. 
Table 1 - The most frequently used relationships for meta-analysis and weight-analysis (Ordered by dependent constructs).

$\mathbf{N}^{\mathbf{o}}$

(1) Independent Constructs (2)

Dependent Constructs (3)

1 Hedonic Value

2 Relational Capital

3 Utilitarian Value

4 Perceived Ease of Use

5 Perceived Usefulness

6 Satisfaction

7 Service Quality

8 Continuance Intention

9 Affective Commitment

10 Attitude

11 Effort Expectancy

12 Flow

13 Habit

14 Hedonic Outcome Expectations

15 Intrinsic Motivation

16 Perceived Behaviour Control

17 Perceived Ease of Use

18 Perceived Enjoyment

19 Perceived Usefulness

20 Performance

21 Satisfaction

22 Subjective Norm

23 Trust

24 Utilitarian Value

25 Perceived Usefulness

26 Satisfaction

27 Confirmation

28 Context

29 Individualism

30 Time perception

31 Uncertainty Avoidance

32 Confirmation

33 Context

34 Individualism

35 Uncertainty Avoidance

36 Context

37 Individualism

38 Time Perception

39 Uncertainty Avoidance

40 Confirmation $\quad$ Perceived Usefulness

41 Context

42 Disconfirmation

43 Individualism

44 Perceived Ease of Use

45 Time Perception

46 Uncertainty Avoidance

47 Confirmation

48 Disconfirmation

49 Hedonic Benefit

50 Information Quality

51 Perceived Ease of Use

52 Perceived Enjoyment

53 Perceived Usefulness

54 Perceived Value

55 Performance

56 Service Quality

57 Social Benefit

58 System Quality

59 Trust

60 Utilitarian Benefit

\section{\begin{tabular}{|c|c|}
\hline & Meta-analysis \\
\hline
\end{tabular}}

\begin{tabular}{|c|c|c|c|c|} 
Total & $\sum$ & AVG & $\mathbf{Z}-$ & $\begin{array}{c}95 \% \text { confidence } \\
\text { interval (low - }\end{array}$ \\
\hline
\end{tabular}

\begin{tabular}{|c|c|c|c|c|} 
(4) & Sample & of cc & value & high) (8) \\
\hline
\end{tabular}

Affective Commitment

\begin{tabular}{|l|l|}
\hline 5 & 1266 \\
\hline 5 & 1266 \\
\hline 5 & 1266 \\
\hline
\end{tabular}

\begin{tabular}{|l|l|l|l|}
\hline & & & \\
\hline
\end{tabular}

\begin{tabular}{|l|l|l|l|}
\hline 0.258 & 9.381 & 0.206 & 0.309 \\
\hline
\end{tabular}

\begin{tabular}{|l|l|l|l|l|}
\hline 1266 & 0.112 & 3.997 & 0.057 & 0.166 \\
\hline
\end{tabular}

Attitude

Confirmation

Continuance Behaviour

Continuance Intention

(1)

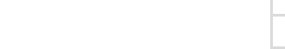

\begin{tabular}{l|l|l|}
\hline 5 & 1209
\end{tabular}

\begin{tabular}{|l|l|l|l|l|l|}
\hline 13 & 4535 & 0.408 & 29.164 & 0.362 & 0.414 \\
\hline
\end{tabular}

\begin{tabular}{|l|l|l|l|l|l|}
\hline 6 & 2580 & 0.481 & 26.615 & 0.451 & 0.510 \\
\hline
\end{tabular}

\begin{tabular}{|l|l|l|l|l|l|}
\hline 4 & 1244 & 0.339 & 12.434 & 0.282 & 0.394 \\
\hline 5 & 1526 & 0.375 & 15.385 & 0.331 & 0.417 \\
\hline
\end{tabular}

\begin{tabular}{|l|l|l|l|l|l|l|}
\hline 5 & 1266 & 0.556 & 22.284 & 0.517 & 0.593 \\
\hline
\end{tabular}

\begin{tabular}{|l|l|l|l|l|l|l|}
\hline 14 & 5657 & 0.441 & 35.602 & 0.409 & 0.458 \\
\hline
\end{tabular}

\begin{tabular}{|l|l|l|l|l|l|}
\hline 3 & 1075 & 0.253 & 8.467 & 0.196 & 0.308 \\
\hline
\end{tabular}

\begin{tabular}{|l|l|l|l|l|l|l|}
\hline 5 & 1243 & 0.358 & 13.207 & 0.308 & 0.406 \\
\hline
\end{tabular}

\begin{tabular}{|l|l|l|l|l|l|l|}
\hline 5 & 1691 & 0.255 & 10.713 & 0.210 & 0.299 \\
\hline
\end{tabular}

\begin{tabular}{|c|c|c|c|c|c|c|}
\hline 7 & 1951 & 0.437 & 20.679 & 0.435 & 0.567 \\
\hline 3 & 508 & 0.453 & 10.977 & 0.381 & 0.520 \\
\hline
\end{tabular}

\begin{tabular}{|l|l|l|l|l|l|}
\hline 3 & 508 & 0.453 & 10.977 & 0.381 & 0.520 \\
\hline 7 & 3021 & 0.296 & 16.763 & 0.263 & 0.328 \\
\hline
\end{tabular}

\begin{tabular}{|l|l|l|l|l|l|}
\hline 6 & 2280 & 0.074 & 3.538 & 0.013 & 0.104 \\
\hline
\end{tabular}

\begin{tabular}{|l|l|l|l|l|l|}
\hline 16 & 5808 & 0.187 & 14.417 & 0.158 & 0.210 \\
\hline
\end{tabular}

\begin{tabular}{|c|c|c|c|c|c|c|}
\hline 41 & 13686 & 0.285 & 34.287 & 0.265 & 0.297 \\
\hline 5 & 3707 & 0.241 & 14.962 & 0.210 & 0.271 \\
\hline
\end{tabular}

\begin{tabular}{|c|c|c|c|c|c|c|}
\hline 5 & 3707 & 0.241 & 14.962 & 0.210 & 0.271 \\
\hline 74 & 29220 & 0.416 & 75.695 & 0.399 & 0.419 \\
\hline
\end{tabular}

\begin{tabular}{|c|c|c|c|c|c|}
\hline 74 & 29220 & 0.416 & 75.695 & 0.399 & 0.419 \\
\hline 11 & 4379 & 0.179 & 11.970 & 0.150 & 0.208 \\
\hline
\end{tabular}

\begin{tabular}{|c|c|c|c|c|c|}
\hline 7 & 2353 & 0.239 & 11.814 & 0.175 & 0.260 \\
\hline 9 & 498 & 0.242 & 5.493 & 0.157 & 0.323 \\
\hline
\end{tabular}

\begin{tabular}{|l|l|l|l|l|l|}
\hline 3 & 4149 & 0.133 & 4.529 & 0.076 & 0.189 \\
\hline
\end{tabular}

Disconfirmation

Habit

Perceived Ease of Use

$3 \quad 755$

\begin{tabular}{|l|l|l|l|l|}
\hline 755 & 0.456 & 13.499 & 0.397 & 0.511 \\
\hline
\end{tabular}

\begin{tabular}{|l|l|l|l|l|l|}
\hline 1511 & 0.458 & 19.214 & 0.471 & 0.548 \\
\hline
\end{tabular}

\begin{tabular}{|l|l|l|l|l|l|}
\hline 5121 & 0.233 & 16.981 & 0.207 & 0.259 \\
\hline
\end{tabular}

\begin{tabular}{|l|l|l|l|l|l|}
\hline 5121 & 0.300 & 22.143 & 0.275 & 0.325 \\
\hline
\end{tabular}

\begin{tabular}{|l|l|l|l|l|}
\hline 5121 & 0.177 & 12.797 & 0.150 & 0.203 \\
\hline
\end{tabular}

\begin{tabular}{|l|l|l|l|l|}
\hline 5121 & -0.137 & -9.863 & -0.164 & -0.110 \\
\hline
\end{tabular}

\begin{tabular}{|l|l|l|l|l|}
\hline 2145 & 0.622 & 33.705 & 0.607 & 0.663 \\
\hline
\end{tabular}

Perceived Enjoyment

5145

\begin{tabular}{|l|l|l|}
5121 & 0.157 & 11.325 \\
\hline
\end{tabular}

\begin{tabular}{|l|l|l|}
5121 & 0.223 & 16.226 \\
\hline
\end{tabular}

\begin{tabular}{|l|l|l|}
5121 & -0.137 & -9.863 \\
\hline
\end{tabular}

\begin{tabular}{|l|l|l|}
\hline 5121 & 0.200 & 14.504 \\
\hline
\end{tabular}

\begin{tabular}{|l|l|l|}
5121 & 0.323 & 23.965 \\
\hline
\end{tabular}

\begin{tabular}{|l|l|l|}
\hline 5121 & 0.190 & 13.760 \\
\hline
\end{tabular}

512

$-0.233$

10168
5121

\begin{tabular}{|l|l|l|}
\hline 1825 & 0.555 & 26.703 \\
\hline 5121 & 0.287 & 21.125 \\
\hline
\end{tabular}

3532

5121

\begin{tabular}{|l|l|}
0.327 & 20.166 \\
\hline
\end{tabular}

\begin{tabular}{|l|l|}
\hline 0.327 & 20.166 \\
\hline 0.177 & 12.797 \\
\hline-0.170 & -12.281
\end{tabular}

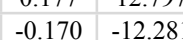

Satisfaction

\begin{tabular}{l|l}
\hline 3 & 5121 \\
\hline 3 & 5121 \\
\hline
\end{tabular}

\begin{tabular}{|l|l|l|}
\hline 12.797 & -0.196 & -0.143 \\
\hline 48.176 & 0.395 & 0.427 \\
\hline
\end{tabular}

\begin{tabular}{|c|c|c|c|c|c|c|}
\hline 3 & 10918 & 0.431 & 48.176 & 0.395 & 0.427 \\
\hline 9 & 2576 & 0.576 & 33.299 & 0.550 & 0.601 \\
\hline
\end{tabular}

\begin{tabular}{|l|l|l|l|l|l|l|}
\hline 3 & 928 & 0.349 & 11.080 & 0.291 & 0.404 \\
\hline
\end{tabular}

\begin{tabular}{|l|l|l|l|l|l|}
\hline 5 & 1735 & 0.248 & 10.541 & 0.203 & 0.292 \\
\hline
\end{tabular}

\begin{tabular}{|l|l|l|l|l|l|}
\hline 10 & 7112 & 0.188 & 16.042 & 0.148 & 0.194 \\
\hline
\end{tabular}

\begin{tabular}{|l|l|l|l|l|l|l|}
\hline 12 & 8018 & 0.251 & 22.962 & 0.230 & 0.271 \\
\hline
\end{tabular}

\begin{tabular}{|l|l|l|l|l|l|l|}
\hline 46 & 18018 & 0.248 & 33.995 & 0.217 & 0.245 \\
\hline 3 & 1158 & 0.203 & 6.996 & 0.147 & 0.258 \\
\hline
\end{tabular}

\begin{tabular}{|l|l|l|l|l|l|l|}
\hline 3 & 1158 & 0.203 & 6.996 & 0.147 & 0.258 \\
\hline
\end{tabular}

\begin{tabular}{|l|l|l|l|l|l|l|}
\hline 3 & 2579 & 0.390 & 20.901 & 0.357 & 0.422 \\
\hline
\end{tabular}

\begin{tabular}{|c|c|c|c|c|c|c|}
\hline 5 & 2608 & 0.296 & 15.574 & 0.058 & 0.151 \\
\hline 3 & 928 & 0.334 & 10.563 & 0.160 & 0.282 \\
\hline
\end{tabular}

\begin{tabular}{|c|c|c|c|c|c|}
\hline 3 & 928 & 0.334 & 10.563 & 0.160 & 0.282 \\
\hline 7 & 2477 & 0.279 & 14.255 & 0.242 & 0.315 \\
\hline
\end{tabular}

\begin{tabular}{|l|l|l|l|l|l|}
\hline 3 & 880 & 0.313 & 9.591 & 0.252 & 0.371 \\
\hline 3 & 928 & 0.182 & 5.598 & 0.119 & 0.244 \\
\hline
\end{tabular}

\begin{tabular}{|c|c|c|c|c|c|}
\hline 3 & 928 & 0.182 & 5.598 & 0.119 & 0.2 \\
\hline
\end{tabular}

Note: The highlighted relationships are the best predictors of the weight analysis.
AVG of $\mathrm{cc}=$ average of the correlation coefficient; Z-value = normal standard deviation.
Weight analysis

Total Weight

cant icant $\begin{aligned} & \text { Total } \\ & \text { (11) }\end{aligned}$ \begin{tabular}{ll|l|l}
$(9)$ & $(10)$ & $(11)$ & Total) (12)
\end{tabular} 
Table 2 - Moderations analysis

\begin{tabular}{|c|c|c|c|c|c|c|c|}
\hline \multicolumn{2}{|c|}{ Moderator Level } & \multicolumn{3}{|c|}{$\begin{array}{l}\text { Perceived Usefulness to } \\
\text { Continuance Intention }\end{array}$} & \multicolumn{3}{|c|}{$\begin{array}{l}\text { Satisfaction to Continuance } \\
\text { Intention }\end{array}$} \\
\hline & & $\beta$ & $\mathrm{R}$ & $P$ _value & $\beta$ & $\mathrm{R}$ & $P_{\text {_value }}$ \\
\hline \multirow[t]{3}{*}{ Sample size } & Intercept & .338 & & .001 & .502 & & .001 \\
\hline & High & 1 & .316 & & 1 & .448 & \\
\hline & Low & .159 & .418 & $.038 * *$ & .049 & .461 & .409 \\
\hline \multirow[t]{3}{*}{ Economic development } & Intercept & .467 & & .001 & .546 & & .001 \\
\hline & High & 1 & .380 & & 1 & .466 & \\
\hline & Low & -.067 & .364 & .454 & -.026 & .451 & .712 \\
\hline \multirow[t]{3}{*}{ Innovation Level } & Intercept & .490 & & .001 & .491 & & .001 \\
\hline & High & 1 & .414 & & 1 & 438 & \\
\hline & Low & -.125 & .330 & .163 & .094 & .492 & .113 \\
\hline \multirow[t]{3}{*}{ Power Distance } & Intercept & .497 & & .001 & .455 & & .001 \\
\hline & High & 1 & .445 & & 1 & .414 & \\
\hline & Low & -.125 & .320 & .158 & .143 & .495 & $.015 * *$ \\
\hline \multirow[t]{3}{*}{ Individualism } & Intercept & .499 & & .001 & .526 & & .001 \\
\hline & High & 1 & .420 & & 1 & .449 & \\
\hline & Low & -.166 & .308 & $.055^{*}$ & .015 & .393 & .836 \\
\hline \multirow[t]{3}{*}{ Masculinity } & Intercept & .511 & & .001 & .527 & & .001 \\
\hline & High & 1 & .435 & & 1 & .465 & \\
\hline & Low & -.138 & .336 & .153 & -.118 & .374 & $.060 *$ \\
\hline \multirow[t]{3}{*}{ Uncertainty avoidance } & Intercept & .361 & & .001 & .473 & & .001 \\
\hline & High & 1 & .327 & & 1 & .430 & \\
\hline & Low & .159 & .441 & $.096 *$ & .018 & .433 & .772 \\
\hline \multirow[t]{3}{*}{ Long Term orientation } & Intercept & .332 & & .001 & .540 & & .001 \\
\hline & High & 1 & .308 & & 1 & .455 & \\
\hline & Low & 166 & .420 & $.055^{*}$ & -.020 & .453 & .769 \\
\hline \multirow[t]{3}{*}{ Indulgence } & Intercept & .394 & & .001 & .584 & & .001 \\
\hline & High & 1 & .343 & & 1 & .484 & \\
\hline & Low & .063 & .408 & .431 & -.115 & .425 & $.053 *$ \\
\hline
\end{tabular}




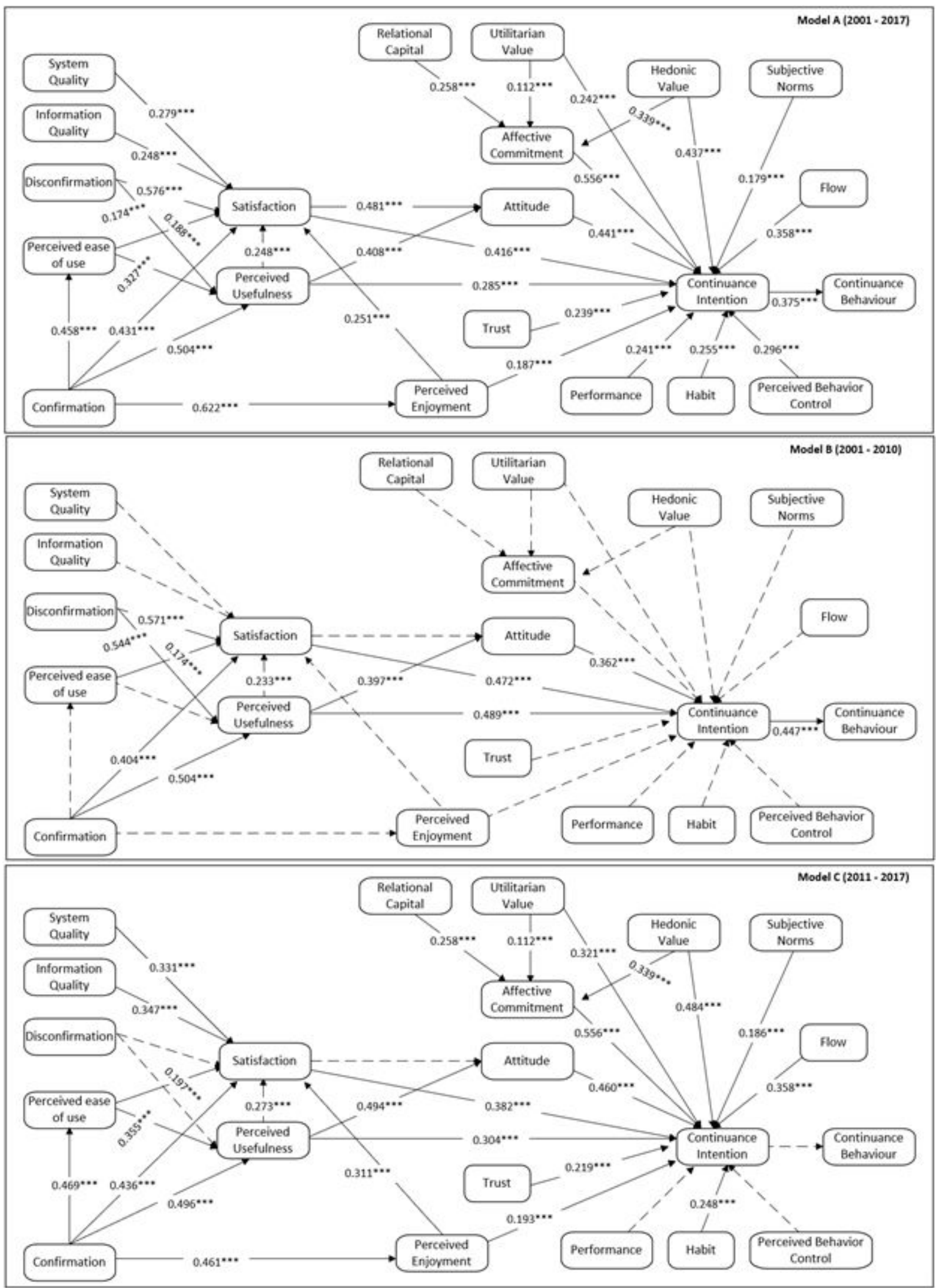

Figure 3 - Theoretical models based on meta- and weight analysis $(* * * p<0.01 ; * * p<0.05 ; * p<0.10)$. Note: The dashed relationships represented above were not statistically significant and best predictors in the period of analysis. 
Appendix A - Research studies used in meta-analysis and weight analysis (Ordered by sample size).

\begin{tabular}{|c|c|c|c|c|}
\hline Study & Country & Sample & Theory & Technology \\
\hline $\begin{array}{l}\text { Mohammadyari and } \\
\text { Singh, } 2015\end{array}$ & New Zealand & 34 & $\begin{array}{l}\text { Digital literacy and unified theory } \\
\text { of acceptance and use of } \\
\text { technology }\end{array}$ & E-learning \\
\hline $\begin{array}{l}\text { Bhattacherjee et al., } \\
2008\end{array}$ & Ukraine & 81 & $\begin{array}{l}\text { Theory of reasoned action, theory } \\
\text { of planed behaviour and } \\
\text { expectation confirmation model }\end{array}$ & DMS - lotus notes \\
\hline Ifinedo, 2017 & Canada & 108 & $\begin{array}{l}\text { Social-cognitive theory, technology } \\
\text { acceptance model and motivation } \\
\text { theory }\end{array}$ & Blogs for learning \\
\hline Gallego et al., 2016 & Spain & 116 & Gratifications theory & Social virtual worlds \\
\hline Bhattacherjee, 2001 & United States of America & 122 & Expectation confirmation theory & Online banking \\
\hline Sørebø et al., 2009 & Norway & 124 & $\begin{array}{l}\text { Self-determination theory and } \\
\text { expectation disconfirmation model }\end{array}$ & E-learning \\
\hline Cheung et al., 2013 & Hong Kong & 124 & $\begin{array}{l}\text { Knowledge sharing, expectation } \\
\text { disconfirmation theory and social } \\
\text { cognitive theory }\end{array}$ & Online community \\
\hline $\begin{array}{l}\text { Barnes and } \\
\text { Böhringer, } 2011\end{array}$ & $\begin{array}{l}\text { Germany, United States of } \\
\text { America, United } \\
\text { Kingdom, etc. }\end{array}$ & 131 & ECM, habit and critical mass & Microblogging twitter \\
\hline $\begin{array}{l}\text { Budiardjo et al., } \\
2017\end{array}$ & Indonesia & 131 & $\begin{array}{l}\text { DeLone and Mclean information } \\
\text { system success model and ECM }\end{array}$ & $\begin{array}{l}\text { Knowledge management } \\
\text { system }\end{array}$ \\
\hline Hong et al., 2016b & Taiwan & 132 & $\begin{array}{l}\text { Cognitive-Affective Theory of } \\
\text { Learning with Media }\end{array}$ & YouTube \\
\hline Larsen et al., 2009 & Norway & 135 & ECM, task technology fit & E-learning \\
\hline Hsu and Chiu, 2004 & Taiwan & 149 & TPB & Web-based tax filing service \\
\hline Hong et al., $2017 \mathrm{~b}$ & Taiwan & 150 & ECM & Government E-learning \\
\hline $\begin{array}{l}\text { Yoon and Rolland, } \\
2015\end{array}$ & South Korea & 150 & ECT & Social networking services \\
\hline Carillo et al., 2015 & Italy & 150 & $\begin{array}{l}\text { Information system continuance } \\
\text { model }\end{array}$ & $\begin{array}{l}\text { Ubiquitous media systems - } \\
\text { smartphone }\end{array}$ \\
\hline Chang et al., 2014 & Taiwan & 166 & SCT and Flow theory & Online games \\
\hline Joo et al., 2018 & Korea & 166 & $\begin{array}{l}\text { Self-determination theory, TAM, } \\
\text { and ECM }\end{array}$ & K-MOOC \\
\hline $\begin{array}{l}\text { Kaewkitipong et al., } \\
2016\end{array}$ & Thailand & 169 & UTAUT and ECM & Social media \\
\hline Roca et al., 2006 & Spain & 172 & TAM, TRA and TPB & E-learning \\
\hline $\begin{array}{l}\text { Premkumar and } \\
\text { Bhattacherjee, } 2008\end{array}$ & United States of America & 175 & TAM and ED & Computer-based training \\
\hline Bøe et al., 2015 & Norway & 177 & ECM and Agency theory & E-learning Technology \\
\hline Chiu et al., 2005 & Taiwan & 183 & $\begin{array}{l}\text { EDT, Perceived performance } \\
\text { component }\end{array}$ & E-learning \\
\hline $\begin{array}{l}\text { Sällberg and } \\
\text { Bengtsson, } 2016\end{array}$ & Sweden & 192 & Motivational model & Computer and smartphone \\
\hline Kim et al., 2009 & Korea & 192 & $\begin{array}{l}\text { Social learning theory and theory of } \\
\text { innovation }\end{array}$ & Mobile banking \\
\hline Chen et al., 2015 & Taiwan & 195 & $\begin{array}{l}\text { ECM, Perceived voluntariness and } \\
\text { habit }\end{array}$ & Teaching blogs \\
\hline Pereira et al., 2015 & Brazil & 197 & $\begin{array}{l}\text { EDT and Virtual learning } \\
\text { environment }\end{array}$ & E-learning \\
\hline Hong et al., 2016a & Taiwan & 200 & Gratifications theory & Educational games \\
\hline Chiu et al., 2007 & Taiwan & 202 & $\begin{array}{l}\text { Subjective task value and fairness } \\
\text { theory }\end{array}$ & E-learning \\
\hline Hong et al., 2015 & Taiwan & 203 & ECM and Social anxiety & Facebook \\
\hline Kim, 2010 & South Korea & 207 & ECM and TPB & Mobile data service \\
\hline Joo et al., 2016 & Korea & 222 & TAM and ECM & $\begin{array}{l}\text { Mobile learning management } \\
\text { system }\end{array}$ \\
\hline Limayem et al., 2007 & Hong Kong & 227 & $\begin{array}{l}\text { ECM, Habit, Frequency of past } \\
\text { behaviour and comprehensiveness } \\
\text { of usage }\end{array}$ & World Wide Web \\
\hline Lin et al., 2011 & Taiwan & 230 & $\begin{array}{l}\text { TRA, negative critical incident and } \\
\text { satisfaction }\end{array}$ & E-learning \\
\hline Song et al., 2017 & United States of America & 236 & ТPB & $\begin{array}{l}\text { Smart-connected sports } \\
\text { products }\end{array}$ \\
\hline Jin et al., 2010 & China & 240 & ECM & Online communities \\
\hline Zhang et al., 2017a & China & 240 & $\begin{array}{l}\text { Theory of community social } \\
\text { organisations and motivation theory }\end{array}$ & Social network services \\
\hline
\end{tabular}




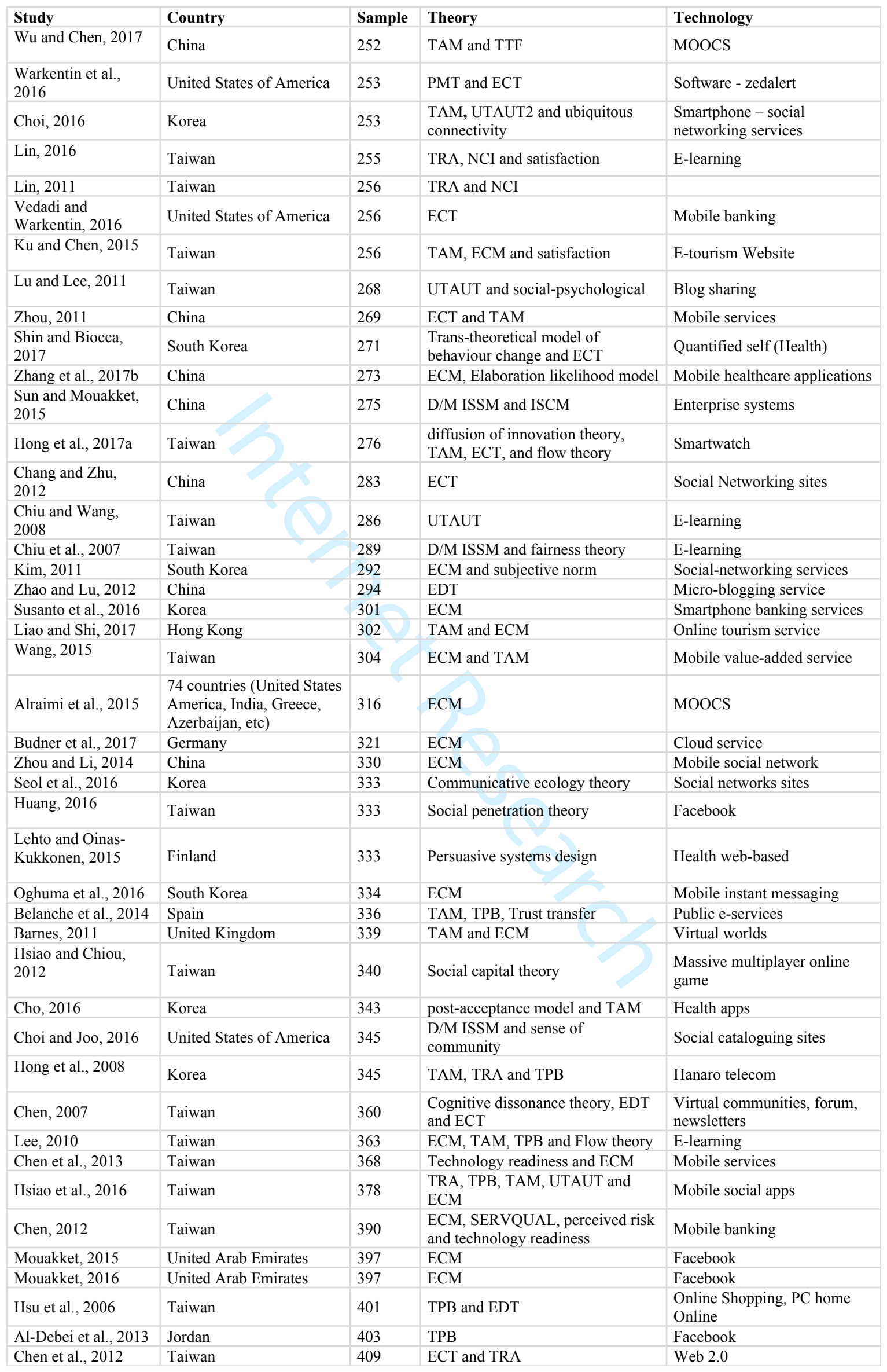




\begin{tabular}{|c|c|c|c|c|}
\hline Study & Country & Sample & Theory & Technology \\
\hline Chong, 2015 & China & 410 & $\begin{array}{l}\text { ECM, perceived ease of use, } \\
\text { perceived usefulness, Trust and } \\
\text { perceived cost }\end{array}$ & M-commerce \\
\hline Lee and Kwon, 2011 & Korea & 420 & ECM, familiarity and intimacy & Online shopping service \\
\hline $\begin{array}{l}\text { Steelman and Soror, } \\
2017\end{array}$ & United States of America & 436 & $\begin{array}{l}\text { ECT and cognitive dissonance } \\
\text { theory }\end{array}$ & Mobile phone \\
\hline Zhou et al., 2012 & China & 438 & Dedication-constraint framework & Social virtual world services \\
\hline Liao et al., 2006 & Taiwan & 446 & $\begin{array}{l}\text { Trust, habit and continuance } \\
\text { intention }\end{array}$ & B2C web site \\
\hline Yang and Lin, 2017 & Taiwan & 451 & Theory of consumption values & $\begin{array}{l}\text { Social network services, } \\
\text { location-based services, and } \\
\text { mobile technologies }\end{array}$ \\
\hline Gao et al., 2015 & China & 462 & D/M ISSM, flow theory and trust & Mobile purchase \\
\hline $\begin{array}{l}\text { Dathan and } \\
\text { Akkoyunlu, } 2016\end{array}$ & Turkey & 467 & $\begin{array}{l}\text { Technology continuance theory, } \\
\text { cognitive model and ECM }\end{array}$ & E-learning \\
\hline Lowry et al., 2015 & $\begin{array}{l}\text { Hong Kong, China and } \\
\text { Taiwan }\end{array}$ & 477 & EDT and ECM & $\begin{array}{l}\text { Gaming website, Wikipedia, } \\
\text { amazon mechanical Turk }\end{array}$ \\
\hline Chen et al., 2009 & Taiwan & 481 & $\begin{array}{l}\text { TAM, TPB and technology } \\
\text { readiness }\end{array}$ & $\begin{array}{l}\text { E-reservation/ticketing, } \\
\text { kiosks, ATM, internet or } \\
\text { mobile } \\
\text { banking/finance/investment }\end{array}$ \\
\hline $\begin{array}{l}\text { Lin and } \\
\text { Bhattacherjee, } 2010\end{array}$ & Taiwan & 485 & $\begin{array}{l}\text { ECM and interactive hedonic } \\
\text { systems }\end{array}$ & Online video games \\
\hline Krasnova et al., 2017 & Germany & 488 & $\begin{array}{l}\text { ECM, gratification theory, and self- } \\
\text { construal theory }\end{array}$ & Social networking sites \\
\hline $\begin{array}{l}\text { Limayem and } \\
\text { Cheung, } 2008\end{array}$ & Hong Kong & 505 & ECM, habit and prior behaviour & Internet-based Learning \\
\hline $\begin{array}{l}\text { Limayem and } \\
\text { Cheung, } 2011\end{array}$ & Hong Kong & 505 & ECM and Habit & Internet-based learning \\
\hline $\begin{array}{l}\text { Hsiao and Chang, } \\
2014\end{array}$ & Taiwan & 508 & ECM, TRA and TAM & Mobile advertising \\
\hline $\begin{array}{l}\text { Abbas and Hamdy, } \\
2015\end{array}$ & Kuwait & 512 & SERVQUAL & Mobile service provider \\
\hline $\begin{array}{l}\text { Bhattacherjee and } \\
\text { Lin, } 2014\end{array}$ & Taiwan & 514 & ECM & Insurance company \\
\hline Lin et al., 2017 & United States of America & 523 & $\begin{array}{l}\text { ECM and social network sites } \\
\text { construct }\end{array}$ & Facebook \\
\hline $\begin{array}{l}\text { Amoroso and Lim, } \\
2017\end{array}$ & Philippine & 528 & ECM & Mobile applications \\
\hline Zhong et al., 2015 & China & 543 & TPB and ECM & Mobile travel booking service \\
\hline $\begin{array}{l}\text { Hadji and Degoulet, } \\
2016\end{array}$ & France & 571 & TAM, UTAUT and ECM & Clinical information system \\
\hline Lu et al., 2017 & United States of America & 584 & UTAUT2 and ECT & Mobile application \\
\hline French et al., 2017 & United States of America & 593 & $\begin{array}{l}\text { TPB, self-determination theory and } \\
\text { social capital }\end{array}$ & $\begin{array}{l}\text { Social networking tourism } \\
\text { sites }\end{array}$ \\
\hline Kang and Lee, 2015 & Korea & 600 & SCT & IM service - NateOn \\
\hline $\begin{array}{l}\text { Lankton and } \\
\text { McKnight, } 2012\end{array}$ & United States of America & 600 & EDT and performance & Microsoft access \\
\hline $\begin{array}{l}\text { Bhattacherjee and } \\
\text { Premkumar, } 2004\end{array}$ & United States of America & 613 & EDT and TAM & $\begin{array}{l}\text { Computer-based training, } \\
\text { rapid application development } \\
\text { software }\end{array}$ \\
\hline Liang et al., 2013 & Taiwan & 623 & TTF and TPB & Mobile services \\
\hline Lin et al., 2014 & United States of America & 742 & Self-regulation theory & Facebook \\
\hline Kang, 2014 & United States of America & 755 & $\begin{array}{l}\text { Motivational communication } \\
\text { theory and TAM }\end{array}$ & Mobile application \\
\hline Zhou et al., 2015 & $\begin{array}{l}\text { United States of America, } \\
\text { Great Britain, etc }\end{array}$ & 828 & $\begin{array}{l}\text { Perceived benefits, affective } \\
\text { commitment and ECM }\end{array}$ & Social virtual world \\
\hline Zhou et al., 2014 & China & 928 & $\begin{array}{l}\text { Fulfilment perspective, and Social } \\
\text { benefits }\end{array}$ & Social virtual world \\
\hline $\begin{array}{l}\text { Ahmad and Sun, } \\
2018\end{array}$ & China and Pakistan & 496,441 & $\begin{array}{l}\text { ECM, Perceived risk and perceived } \\
\text { value }\end{array}$ & $\begin{array}{l}\text { Social media mobile } \\
\text { applications }\end{array}$ \\
\hline Zhao et al., 2012 & China & 1075 & SERVQUAL and justice & Mobile value-added services \\
\hline Chou et al., 2010 & China, Taiwan & 2229 & $\begin{array}{l}\text { ECT, Perceived identity } \\
\text { verification and perceived } \\
\text { usefulness }\end{array}$ & Baidu and yahoo \\
\hline Lee et al., 2007 & $\begin{array}{l}\text { Korea, Hong Kong, } \\
\text { Taiwan }\end{array}$ & 5121 & TAM and interaction theory & Mobile internet \\
\hline
\end{tabular}

Notes: Unified theory of acceptance and use of technology (UTAUT), theory of reasoned action (TRA), theory of planed behaviour (TPB), expectation confirmation model (ECM), technology acceptance model (TAM), expectation confirmation theory (ECT), 
expectation disconfirmation model (EDM), social cognitive theory (SCT), task technology fit (TTF), media system dependency theory (MDT), expectation disconfirmation theory (EDT), negative critical incident (NCI), information system continuance model (ISCM), protection motivation theory (PMT), DeLone and Mclean information system success model (D/M ISSM), diffusion of innovation theory (DIT), post-acceptance model (PAM), technology continuance theory (TCT), service quality (SERVQUAL), and selfdetermination theory (SDT).

Appendix B - Number of research studies by Journal.

\begin{tabular}{|c|c|c|c|c|c|c|c|c|c|c|c|c|c|c|c|}
\hline $\mathrm{N}^{\mathrm{o}}$ & Journal & $2001-05$ & 2006 & 2007 & 2008 & 2009 & 2010 & 2011 & 2012 & 2013 & 2014 & 2015 & 2016 & 2017 & Total \\
\hline 1 & AIS Transactions on Replication Research & & & & & & & & & & & & 1 & 1 & 2 \\
\hline 2 & Behaviour and Information Technology & 1 & & & & & 2 & 4 & & & 1 & 2 & 1 & & 11 \\
\hline 3 & Computers and Education & 1 & & 1 & & 1 & 1 & 1 & & & & 3 & 2 & 1 & 11 \\
\hline 5 & Computers in Industry & & & & & & & & & & & 1 & & & 1 \\
\hline 6 & $\begin{array}{l}\text { Cyberpsychology, Behaviour, and Social } \\
\text { Networking }\end{array}$ & & & & & & & 1 & & 1 & & & & & 2 \\
\hline 7 & Decision Support Systems & & & & & & & & 2 & 1 & 1 & & 1 & & 5 \\
\hline 8 & $\begin{array}{l}\text { Educational Technology Research and } \\
\text { Development }\end{array}$ & & & & & & & & & & & & 1 & & 1 \\
\hline 9 & $\begin{array}{l}\text { Electronic Commerce Research and } \\
\text { Applications }\end{array}$ & & & & & & & 1 & & & & & & & 1 \\
\hline 10 & European Journal of Information Systems & 28 & & & & & & & & & 1 & 1 & & & 2 \\
\hline 11 & Expert Systems with Applications & $=$ & & & & & 1 & & & & & & & & 1 \\
\hline 12 & Industrial Management and Data Systems & (N) & & & & 1 & & & & & & & 1 & & 2 \\
\hline 13 & Information and Management & $\forall$ & & & 2 & & & 1 & 1 & & 2 & 2 & & 3 & 11 \\
\hline 15 & Information Technology for Development & & & & & & & & & & & & & 1 & 1 \\
\hline 16 & $\begin{array}{l}\text { International Journal of Business and } \\
\text { Management }\end{array}$ & & & & & & & & & & & 1 & & & 1 \\
\hline 17 & $\begin{array}{l}\text { International Journal of Electronic } \\
\text { Commerce }\end{array}$ & & & 1 & & & & & & & & & & & 1 \\
\hline 18 & $\begin{array}{l}\text { International Journal of Human-Computer } \\
\text { Studies }\end{array}$ & & 2 & & & & & & & & & & & & 2 \\
\hline 19 & $\begin{array}{l}\text { International Journal of Information } \\
\text { Management }\end{array}$ & & 1 & & & & & & & & & & & 1 & 2 \\
\hline 20 & International Journal of Medical Informatics & & & & 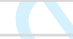 & 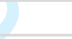 & & & & & & & 1 & & 1 \\
\hline 21 & $\begin{array}{l}\text { International Journal of Mobile } \\
\text { Communications }\end{array}$ & & & & 8 & & & & 1 & 1 & 1 & & & & 3 \\
\hline 22 & Internet Research & & & & & & 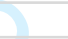 & & & & 1 & & & & 1 \\
\hline 23 & Journal of Biomedical Informatics & & & & & & V & & & & & & 1 & & 1 \\
\hline 24 & Journal of Computer Information Systems & & & & 2 & & & 1 & & 1 & & 1 & 1 & 1 & 7 \\
\hline 25 & $\begin{array}{l}\text { Journal of Global Information Technology } \\
\text { Management }\end{array}$ & & & & & & & & & & & & & 1 & 1 \\
\hline 27 & Journal of Information Science & & & 1 & & & & & 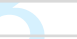 & & & & & & 1 \\
\hline 28 & $\begin{array}{l}\text { Journal of Information Systems and } \\
\text { Technology Management }\end{array}$ & & & & & & & & & & & 1 & & & 1 \\
\hline 29 & $\begin{array}{l}\text { Journal of Management Information } \\
\text { Systems }\end{array}$ & & & & & & & & 1 & & & & & & 1 \\
\hline 30 & $\begin{array}{l}\text { Journal of the American Society for } \\
\text { Information Science and Technology }\end{array}$ & & & & & & & & & 1 & & & & & 1 \\
\hline 31 & $\begin{array}{l}\text { Journal of the Association for Information } \\
\text { Science and Technology }\end{array}$ & & & & & & & & & & & & 1 & & 1 \\
\hline 32 & $\begin{array}{l}\text { Journal of the Association for Information } \\
\text { Systems }\end{array}$ & & & & & & & & 1 & & & 1 & & & 2 \\
\hline 33 & Journal of Retailing and Consumer Services & & & & & & & & & & & & & 1 & 1 \\
\hline 34 & Journal of Strategic Information Systems & & & & & & & & & & & & & 1 & 1 \\
\hline 35 & $\begin{array}{l}\text { Knowledge Management and E-Learning: } \\
\text { An International Journal }\end{array}$ & & & & & & & & & & & & & 1 & 1 \\
\hline 36 & MIS Quarterly & 2 & & 1 & & & & & & & & & & & 3 \\
\hline 37 & Omega & & & & 1 & & & & & & & & & & 1 \\
\hline 38 & Service Business & & & & & & & & & & & 1 & & & 1 \\
\hline 39 & Sport Management Review & & & & & & & & & & & & & 1 & 1 \\
\hline 40 & Telematics and Informatics & & & & & & & & & & & & 2 & & 2 \\
\hline & Total & 4 & 3 & 5 & 5 & 4 & 5 & 9 & 8 & 5 & 8 & 19 & 18 & 22 & 115 \\
\hline
\end{tabular}

Note: The highlighted journals have more than ten publications. 
Appendix C: Definition of variable names

\begin{tabular}{|c|c|c|}
\hline Study & Original variable name & Selected variable name \\
\hline $\begin{array}{l}\text { Wang, } 2015 \\
\text { Hong et al., 2017b } \\
\text { Zhou and Li, } 2014 \\
\text { Susanto et al., 2016 } \\
\text { Ku and Chen, } 2015 \\
\text { Lowry et al., } 2015 \\
\text { Bhattacherjee, 2001 } \\
\text { Lin and Bhattacherjee, } 2010\end{array}$ & $\begin{array}{l}\text { Continuance Intention } \\
\text { Continuance intention to use } \\
\text { Continuance usage } \\
\text { Continuance Use Intention } \\
\text { Continued Usage Intention } \\
\text { Intention to continue } \\
\text { IS continuance intention } \\
\text { Usage Intention }\end{array}$ & Continuance intention \\
\hline $\begin{array}{l}\text { Yoon and Rolland, } 2015 \\
\text { Oghuma et al., } 2016 \\
\text { Lankton and McKnight, } 2012\end{array}$ & $\begin{array}{l}\text { Perceived Usefulness } \\
\text { Usefulness } \\
\text { Usefulness Expectations }\end{array}$ & Perceived usefulness \\
\hline $\begin{array}{l}\text { Susanto et al., } 2016 \\
\text { Lin et al., } 2011 \\
\text { Yoon and Rolland, } 2015\end{array}$ & $\begin{array}{l}\text { User Satisfaction } \\
\text { Overall Satisfaction } \\
\text { Satisfaction }\end{array}$ & Satisfaction \\
\hline $\begin{array}{l}\text { Chong, } 2015 \\
\text { Chen et al., } 2013\end{array}$ & $\begin{array}{l}\text { Confirmation } \\
\text { Confirmation of Expectations }\end{array}$ & Confirmation \\
\hline $\begin{array}{l}\text { Lu et al., } 2017 \\
\text { Chong, } 2015\end{array}$ & $\begin{array}{l}\text { Enjoyment } \\
\text { Perceived Enjoyment }\end{array}$ & Perceived enjoyment \\
\hline $\begin{array}{l}\text { Premkumar and Bhattacherjee, } 2008 \\
\text { Kang, } 2014\end{array}$ & $\begin{array}{l}\text { Performance } \\
\text { Performance Expectancy }\end{array}$ & Performance \\
\hline
\end{tabular}

Appendix D: Moderators description

\begin{tabular}{|c|c|c|}
\hline Variable & Description & Coding \\
\hline Sample size & $\begin{array}{l}\text { The sample was classified in two groups: small or large. From the sample number } \\
\text { presented in each study, we adopted the median of the sample sizes as the cut-off point. }\end{array}$ & $\begin{array}{l}0=\text { small } \\
1=\text { large }\end{array}$ \\
\hline $\begin{array}{l}\text { Economic } \\
\text { development }\end{array}$ & $\begin{array}{l}\text { Economic development was classified using the country reported in the methodology of } \\
\text { each study. We checked whether the studies came from developed or developing } \\
\text { countries (Zarantonello et al., 2013). }\end{array}$ & $\begin{array}{l}0=\text { developing } \\
1=\text { developed }\end{array}$ \\
\hline Innovation Level & $\begin{array}{l}\text { The innovation level was coded using information from the } \\
\text { Bloomberg Innovation Index 2019. In this case, we obtained the median values of each } \\
\text { country of origin of the studies analysed. }\end{array}$ & $\begin{array}{l}0=\text { low innovation } \\
1=\text { high innovation }\end{array}$ \\
\hline Power Distance & $\begin{array}{l}\text { The power distance was classified using the level (low vs high). The groups were created } \\
\text { using the origin of the study and were based on the parameters established by (Hofstede } \\
\text { and Minkov, 2010) obtained from the median of the indices of each country. }\end{array}$ & $\begin{array}{l}0=\text { low power distance } \\
1=\text { high power distance }\end{array}$ \\
\hline Individualism & $\begin{array}{l}\text { We coded the degree of individualism (low vs high). The groups followed the same } \\
\text { procedures mentioned in the power distance item. }\end{array}$ & $\begin{array}{l}0=\text { low degree of individualism } \\
1=\text { high degree of individualism }\end{array}$ \\
\hline Masculinity & $\begin{array}{l}\text { The degree of masculinity was identified (low vs high). The groups followed the same } \\
\text { procedures mentioned in the power distance item. }\end{array}$ & $\begin{array}{l}0=\text { low degree of masculinity } \\
1=\text { high degree of masculinity }\end{array}$ \\
\hline Uncertainty avoidance & $\begin{array}{l}\text { We coded the groups associated with a low level and a high level of uncertainty } \\
\text { avoidance. The procedure followed the logic established and quoted in the power } \\
\text { distance dimension. }\end{array}$ & $\begin{array}{l}0=\text { low uncertainty avoidance } \\
1=\text { high uncertainty avoidance }\end{array}$ \\
\hline Long Term orientation & $\begin{array}{l}\text { We classified the long-term orientation in two groups (low vs high). Then we have } \\
\text { followed the same procedures mentioned in the power distance. }\end{array}$ & $\begin{array}{l}0=\text { low long-term orientation } \\
1=\text { high long-term orientation }\end{array}$ \\
\hline Indulgence & $\begin{array}{l}\text { The procedures mentioned in the power distance was also used in this cultural dimension } \\
\text { (low and high level of indulgence). }\end{array}$ & $\begin{array}{l}0=\text { low indulgence } \\
1=\text { high indulgence }\end{array}$ \\
\hline
\end{tabular}

